\title{
Molecular characterization of bacteria and archaea in a bioaugmented zero-water exchange shrimp pond
}

\author{
Valsamma Joseph ${ }^{1}$ (1) - Geethu Chellappan ${ }^{1}$ - S. Aparajitha ${ }^{1}$ - R. N. Ramya ${ }^{1}$ - S. Vrinda ${ }^{1}$. V. J. Rejish Kumar ${ }^{1}$. \\ I. S. Bright Singh ${ }^{1}$
}

Received: 29 October 2020 / Accepted: 16 February 2021 / Published online: 15 March 2021

(c) The Author(s) $2021 \quad$ OPEN

\begin{abstract}
In the zero-water exchange shrimp culture pond maintained with the application of indigenous bioaugmentor, low levels of total ammonia-nitrogen were reported, indicating the relevance of indigenous microbial communities. Sediments ( $0-5 \mathrm{~cm}$ layer) were sampled from the pond (85th day) and the bacterial and archaeal communities; specifically, the ammonia oxidizers (ammonia-oxidizing bacteria, ammonia-oxidizing archaea, and anaerobic ammonia-oxidizing bacteria) in the sediment metagenome of the pond were analysed using the $16 \mathrm{~S}$ rRNA and functional genes. Bacterial and archaeal 16S rRNA genes showed the relative abundance of Delta-Proteobacteria and Bacteroidetes groups performing sulphur respiration and organic matter degradation, archaeal groups of anaerobic sulphur respiring Crenarchaeotae, and chemolithoautotrophic ammonia oxidizers belonging to Thaumarchaeota. The presence of these diverse bacterial and archaeal communities denotes their significant roles in the cycling the carbon, nitrogen, and sulphur thereby bringing out efficient bioremediation in the bioaugmented zero-water exchange shrimp culture pond. Similarly, the functional genespecific study showed the predominance of Nitrosomonas sp. (ammonia-oxidizing bacteria), Nitrosopumilus maritimus (ammonia-oxidizing archaea), and Candidatus Kuenenia (anaerobic ammonia-oxidizing bacteria) in the system, which points to their importance in the removal of accumulated ammonia. Thus, this study paves the way for understanding the microbial communities, specifically the ammonia oxidizers responsible for maintaining healthy and optimal environmental conditions in the bioaugmented zero-water exchange shrimp culture pond.
\end{abstract}

Keywords $16 \mathrm{~S}$ rRNA gene $\cdot$ AmoA gene $\cdot$ Ammonia oxidizers $\cdot$ Archaea $\cdot$ Bacteria $\cdot$ Sediment metagenome

\section{Introduction}

Zero-water exchange (ZWE) shrimp culture ponds are environmentally sustainable, bio-secured systems developed as an alternative to traditional open aquaculture production. In open culture systems, water quality is maintained through frequent exchange of water [110]. Frequent release of water into the nearby aquatic systems often causes eutrophication due to excess nutrient contents [93], and the uptake of water for culturing from the neighbouring water bodies also leads to horizontal transfer of pathogens causing subsequent disease outbreak and mortality of shrimp [24]. ZWE aquaculture ponds have been developed to abate the negative impacts of open shrimp farming on the environment. The problem faced by ZWE ponds is the build-up of high organic matter and toxic inorganic nitrogen composed of unutilized feed, fertilizers, and metabolic waste [10]. The concentrations of ammonia-nitrogen (ammonia-N) above the recommended safe levels $[13,14]$ induce less oxygen transport and stress in

Supplementary information The online version of this article (https://doi.org/10.1007/s42452-021-04392-z)

Valsamma Joseph, valsamma@cusat.ac.in | ${ }^{1}$ National Centre for Aquatic Animal Health, Cochin University of Science and Technology, Lakeside Campus, Fine Arts Avenue, Kochi, Kerala 682016, India. 
shrimps, which in turn decrease the immunity leading to morbidity, mortality, and loss of crop [15]. The bioaugmented ZWE shrimp culture ponds with bioaugmentor "Detrodigest ${ }^{\mathrm{TM}}$ " (a preparation containing euryhaline BacilIus cereus MCCB 101, GenBank accession no: EF062509), developed, implemented, and validated by the National Centre for Aquatic Animal Health (NCAAH), Cochin University of Science and Technology (CUSAT), Cochin, India [34], proved to maintain optimal and stable environmental parameters required for shrimp culturing, notably low or negligible concentration of ammonia throughout the culture period $[34,44]$. Bacillus cereus MCCB 101, the sole component of a commercial product Detrodigest ${ }^{\mathrm{TM}}$, is an indigenous Gram-positive bacterium isolated from shrimp pond sediment, with hydrolytic potential, used in aquaculture ponds for detritus degradation.

Bioaugmentation is the process of adding specially formulated microorganisms to improve the water quality through the degradation of organic matter and altering the microbial ecology [68, 87]. Microorganisms, whether they occur naturally or added artificially, are of great importance and play significant roles in pond ecosystems, particularly for its productivity, nutrition of the cultured animals, nutrient cycling, disease control, water quality, and environmental impact [68]. Knowledge of microbial interactions is essential for successful management of the aquaculture practices. The application of bioaugmentor has shown to enhance mineralization of organic matter [62], reduction of nitrogen and phosphorus from the systems, improving the survival and productivity of the cultured animals [117]. The maintenance of optimal and stable environmental parameters in this bioaugmented pond indicated the presence of active indigenous microbial communities in the sediment [68].

Bacterial and archaeal communities play a vital role in oxidative and reductive processes of nitrification [36]. The major challenge faced by aquaculture ponds is the accumulation of toxic ammonia, which at high concentrations can decrease the rate of outward diffusion from the animal, and toxicity exceeds tolerable level [91]. But the ammonium-oxidizing bacteria $(\mathrm{AOB})$ and nitrite-oxidizing bacteria (NOB) of shrimp ponds could oxidize this toxic ammonia to nitrite and then to less toxic form nitrate [50]. Similarly, chemoautotrophic nitrifier, ammonium-oxidizing archaea (AOA) [108], and bacteria performing anaerobic ammonia oxidation (anaerobic ammonium-oxidizing (anammox)) (single-step conversion of ammonia to nitrogen gas) $[40,99]$ are observed $[4,60,119]$ in aquaculture ponds. Therefore, identification of bacterial and archaeal ammonia oxidizers is an important step in understanding the biogeochemical processes.

In general, ninety-nine percent of microbes are unculturable, and especially, the nitrifying bacteria are slow growers and are highly sensitive to environmental conditions; so, it is difficult to isolate them in pure culture [32]. Therefore, for a true understanding of these microbial communities and nitrifiers in an ecosystem, a cultureindependent metagenomic approach is appropriate [32, 79]. The availability of molecular tools and gene sequencing has made it possible to explore the slow-growing or uncultivable bacterial and archaeal species in different environments [55]. PCR amplification and clone libraries of highly conserved regions (bacterial or archaeal 16S rRNA genes and functional genes) are widely used to describes the microbial community [114] in varied ecosystems such as freshwater [107], seawater [94], marine sediments [30], farm sediment [63], zero-discharge mariculture, and aquaculture systems [50]. For the microbial community $16 \mathrm{~S}$ rRNA gene profiling and diversity, a molecular fingerprinting technique ARDRA (amplified ribosomal DNA restriction analysis) was used [64, 78].

The addition of "Detrodigest ${ }^{\mathrm{TM} \prime}$ " $[34,44,84]$ degrades the organic matter and stimulates the natural microbial communities, which in turn help to maintain the optimal environmental conditions for shrimp growth, and therefore, it is important to study the microbial communities and ammonia oxidizers in bioaugmented ZWE shrimp pond. Thus, the present study highlights 1 ) the bacterial and archaeal $16 \mathrm{~S}$ rRNA gene-based community structure and 2) the functional gene-based characterization of ammonia oxidizers like $A O B$ and $A O A$, and anammox specific 16SrRNA gene based chareacterizaiton of anammox bacteria in the ZWE shrimp culture pond from the sediment metagenome collected from a bioaugmented ZWE shrimp pond in Kodungallur, India $\left(10.254639^{\circ} \mathrm{N}, 76.20991^{\circ} \mathrm{E}\right)$ on 85th day of culturing (25th April 2008), with the consent of the farmer. The research was carried out at National Centre for Aquatic Animal Health (NCAAH), CUSAT, Cochin, India, during March 2008 to February 2011.

\section{Materials and methods}

\subsection{Study site, sample collection, and physicochemical characterization}

The sediment samples were collected from a bioaugmented ZWE shrimp culture pond $\left(10,117 \mathrm{~m}^{2}\right)$ with $1 \mathrm{~m}$ depth located at Kodungallur, India $\left(10.254639^{\circ} \mathrm{N}\right.$, $76.20991^{\circ} \mathrm{E}$ ), on 25th April 2008 on the 85th day of culture (prior to harvest). The samples were collected on the 85th days of the culture, the time most intense microbial activity, when there were maximum biomass, feed input, and faecal matter output, but the ammonia concentrations were negligible. The pond was maintained by the 
application of indigenous bioaugmentor "Detrodigest ${ }^{\mathrm{TM}}$ ", every 7 days.

The top $0-5 \mathrm{~cm}$ layer of sediment was collected from five different sites of the pond and maintained in refrigerated condition. Composite sediment samples were prepared and stored at $-80^{\circ} \mathrm{C}$ for DNA extraction.

The analysis of water quality parameters was carried out in triplicates. The salinity was measured using refractometer, $\mathrm{pH}$ using digital $\mathrm{pH}$ metre (Scientific Tech, India), alkalinity and hardness by titrimetric method [5]., and ammonia-nitrogen (ammonia-N) by phenol hypochlorite method [95]. Briefly, $10 \mathrm{~mL}$ of water sample was incubated with $0.4 \mathrm{~mL}$ phenol $(20 \mathrm{~g}$ of crystalline phenol dissolved in $95 \% \mathrm{~V} / \mathrm{V}$ ethyl alcohol), $0.4 \mathrm{ml}$ sodium nitroprusside $(1 \mathrm{~g}$ dissolved in $200 \mathrm{~mL}$ distilled water), and $1.0 \mathrm{~mL}$ oxidizing solution (alkaline reagent ( $100 \mathrm{~g}$ sodium citrate and $5 \mathrm{~g}$ sodium hydroxide dissolved in $500 \mathrm{~mL}$ distilled water) and sodium hypochlorite (4:1)). After $1 \mathrm{~h}$, the absorbance was read at $630 \mathrm{~nm}$ using UV-Vis spectrophotometer (Shimadzu, 1650 P( Japan). The factor value was calculated by preparing a series of standards at a concentration of 10 to $60 \mu \mathrm{g}$ ammonia-N (a standard solution of $10 \mu \mathrm{g} \mathrm{mL}^{-1}$ ammonia- $\mathrm{N}$ was prepared by dissolving $4.714 \mathrm{mg}$ ammonium chloride in $100 \mathrm{~mL}$ double-distilled water). Nitrite nitrogen (nitrite-N) was analysed by incubating $10 \mathrm{~mL}$ water sample using $0.2 \mathrm{~mL}$ sulphanilamide $(5 \mathrm{~g}$ dissolved in a mixture of $50 \mathrm{~mL}$ concentrated hydrochloric acid and $450 \mathrm{~mL}$ distilled water) and $0.2 \mathrm{~mL} \mathrm{~N}$-(1-naphthyl)ethylene diamine dihydrochloride (NED dihydrochloride) ( $0.5 \mathrm{~g}$ dissolved in $500 \mathrm{~mL}$ distilled water) [8]. After $8 \mathrm{~min}$, the absorbance was read at $543 \mathrm{~nm}$ using UV-Vis spectrophotometer (Shimadzu, 1650 PC Japan). The factor value was calculated by preparing a series of standards at a concentration of 10 to $60 \mu \mathrm{g}$ nitrite- $\mathrm{N}$ (a standard solution of $10 \mu \mathrm{g} \mathrm{mL}^{-1}$ nitrite-N was prepared by dissolving $4.925 \mathrm{mg}$ sodium nitrite in $100 \mathrm{~mL}$ double-distilled water). Nitrate nitrogen (nitrate-N) [8] was estimated by incubating $10 \mathrm{~mL}$ water sample by adding $0.4 \mathrm{ml}$ phenol-sodium hydroxide solution (1:1), and hydrazine sulphate-copper sulphate solution (1:1) in dark for 18 to $24 \mathrm{~h}$. Phenol-sodium hydroxide solution is prepared by mixing phenol solution $(46 \mathrm{gm}$ dissolved in $1 \mathrm{~L}$ distilled water) and sodium hydroxide ( $30 \mathrm{~g}$ dissolved in $2 \mathrm{~L}$ distilled water), and hydrazine sulphate-copper sulphate solution was prepared by the mixing hydrazine sulphate (14.5 $\mathrm{g}$ hydrazine sulphate dissolved in $1 \mathrm{~L}$ distilled water) and copper sulphate $(0.1 \mathrm{~g}$ copper sulphate dissolved in $1 \mathrm{~L}$ distilled water). After incubation, $0.4 \mathrm{~mL}$ acetone, 0.2 $\mathrm{mL}$ sulphanilamide, and $0.2 \mathrm{~mL}$ NED dihydrochloride were added. Absorbance was measured after $8 \mathrm{~min}$ at $543 \mathrm{~nm}$ using UV-Vis spectrophotometer (Shimadzu, 1650 PC Japan). The factor value was calculated by preparing a series of standards at concentrations of 10 to $60 \mu \mathrm{g}$ nitrate nitrogen (a standard solution of $10 \mu \mathrm{g} \mathrm{mL}^{-1}$ nitrate-N was prepared by dissolving $6.0707 \mathrm{mg}$ sodium nitrate in 100 $\mathrm{mL}$ double-distilled water). The efficiency of the reaction was determined to measure the percentage of nitrate converted into nitrite. The inorganic phosphate was measured by ascorbic acid method [98] by adding $1.6 \mathrm{~mL}$ combined reagent $(5 \mathrm{~mL} 5 \mathrm{~N}$ sulphuric acid $(14 \mathrm{~mL}$ concentrated sulphuric acid diluted to $100 \mathrm{~mL}$ distilled water), $0.5 \mathrm{ml}$ potassium antimonyl tartrate $(0.686 \mathrm{~g}$ dissolved in $250 \mathrm{~mL}$ distilled water), $1.5 \mathrm{~mL}$ ammonium molybdate $(4 \mathrm{~g}$ dissolved in $100 \mathrm{~mL}$ distilled water), and $3 \mathrm{~mL}$ ascorbic acid ( $1.76 \mathrm{~g}$ dissolved in $100 \mathrm{~mL}$ distilled water)) to $10 \mathrm{~mL}$ water sample. Absorbance was measured at $880 \mathrm{~nm}$ after a 10-min incubation using UV-Vis spectrophotometer (Shimadzu, 1650 PC Japan). The factor value was calculated by preparing a series of standards at a concentration of 50 to $600 \mathrm{\mu g} \mathrm{PO}_{4}{ }^{3-} \mathrm{mL}^{-1}$ (54.87 mg anhydrous potassium dihydrogen phosphate dissolved in $250 \mathrm{~mL}$ double-distilled water gave $50 \mu \mathrm{g} \mathrm{PO}_{4}{ }^{3-} \mathrm{mL}^{-1}$ ). All the analyses were performed with triplicate samples with distilled water as blank, and values were represented as mean value.

\section{Metagenomic DNA isolation}

The metagenomic DNA was isolated from sediment sample (250 mg) using Power soil DNA isolation kit following manufacturer's instructions (MoBio Laboratories Inc., USA), and the concentration of the DNA was estimated using a UV spectrophotometer (Hitachi U-2800, Hitachi Corp, Japan) by measuring absorbance at $260 \mathrm{~nm}$.

\section{Polymerase chain reaction (PCR) amplification and library preparation}

PCR amplification was carried out to analyse the bacterial and archaeal 16S rRNA genes, bacterial and archaeal ammonia monooxygenase $\mathrm{A}(\mathrm{amoA})$ functional genes, and $16 \mathrm{~S}$ rRNA gene-specific to anammox bacteria. The details of primers and the annealing temperature used in this study are specified in Table 1. The PCR reactions were processed in a thermal cycler (Eppendorf, Germany). All the genes were amplified using Master Taq DNA amplification kit (5 PRIME, USA), which included $5 X$ Taq Master PCR Enhancer (1X), 10X Master Taq buffer with $\mathrm{Mg}^{2+}(1 \mathrm{X})$, $10 \mathrm{mM}$ dNTP $(0.2 \mathrm{mM})$ of forward and reverse primers, Taq DNA polymerase $(0.04 \mathrm{U})$, and metagenomic DNA (100 $\mathrm{ng}$ ). Triplicate PCR products were pooled, electrophoresed on $1.5 \%(\mathrm{w} / \mathrm{v})$ agarose gel (Sigma-Aldrich, USA), and purified using the GenElute ${ }^{\mathrm{TM}}$ Gel Extraction Kit (SigmaAldrich, USA). The purified PCR products were cloned into the PGEM-T ${ }^{\circledR}$-T Easy Vectors (Promega, USA) for library 
Table 1 PCR primers used for the amplification of bacterial and archaeal $16 \mathrm{~S}$ rRNA genes and functional genes of ammonia oxidizers (AOB, AOA, and anammox)

\begin{tabular}{lllll}
\hline Name & Primer sequence $\left(5^{\prime}\right.$ to $\left.3^{\prime}\right)$ & Annealing $\left({ }^{\circ} \mathrm{C}\right)$ & $\begin{array}{l}\text { Product } \\
\text { Size }(\mathrm{bp})\end{array}$ & Reference \\
\hline Bacterial 16SrRNA & $\begin{array}{l}\text { Bac-fD1-GAGTTTGATCCTGGCTCA } \\
\text { Bac-rP2-ACGGCTACCTTGTTACGACTT }\end{array}$ & 58 & 1500 & {$[114]$} \\
Archaeal 16SrRNA & $\begin{array}{l}\text { Arch-21F-TTCCGGTTG ATCCYGCCGGA } \\
\text { Arch-958R-YCCGGCGTTGAMTCCAATT }\end{array}$ & 55 & 950 & {$[19]$} \\
AOB & $\begin{array}{l}\text { amoA-1F-GGGGTTTCTACTGGTGGT } \\
\text { amoA-2R-CCCCTCKGSAAAGCCTTCTTC }\end{array}$ & 60 & 491 & {$[86]$} \\
AOA & Arch-amoAF-STAATGGTCTGGCTTAGACG & 53 & 635 & {$[26]$} \\
Anammox & Arch-amoAR-GCGGCCATCCATCTGTATGT \\
& Amx 368F-TTCGCAATGCCCGAAAGG & 56 & 478 & {$[3]$} \\
& Amx 820R-AAAACCCCTCTACTTAGTGCCC & & & \\
\hline
\end{tabular}

preparation and transformed, and the screened positive clones were selected for plasmid extraction using GenElute $^{\text {TM }}$ Plasmid Miniprep Kit (Sigma-Aldrich, USA).

\section{Amplified ribosomal DNA restriction analysis (ARDRA)}

Using the purified plasmids (1:200 dilutions), the bacterial and archaeal $16 \mathrm{~S}$ rRNA genes were re-amplified with bacterial- and archaeal-specific 16S rRNA gene primers as mentioned earlier (Table 1), using the same PCR mix and conditions mentioned in the previous section. The re-amplified PCR products were subjected to ARDRA using two tetra cutter restriction enzymes Alul and Haelll (New England Biolabs, USA). The restriction digestion was carried out separately with two units of each restriction enzymes for $3 \mathrm{~h}$ in a twenty micro-litre reaction volume of re-amplified PCR product $5 \mu$, incubation buffer (New England Biolabs, USA) $2 \mu \mathrm{l}$, and Milli-Q water $12.8 \mu \mathrm{l}$. The PCR products were run on 3\% agarose (Sigma-Aldrich, USA) gel in 1XTAE buffer for $3 \mathrm{~h}$ at $100 \mathrm{~V}$ and visualized under UV excitation in a gel documentation system (Bio-Rad, USA). Using the Quantity One (Bio-Rad, USA) software, the band patterns on the gel were scored for the absence (0)/presence (1) of individual loci and analysed using the NTSYSpc (version 2.02i, Applied Biostatistics Inc., USA). Further, using NT edit programme, the data matrix prepared in MS-Excel spreadsheets was converted to a proprietary matrix file, and the rectangular data matrix generated was analysed by NTSYSpc (version 2.02i, Applied Biostatistics Inc., USA). Similarities and clustering were performed using a simple matching coefficient SAHN (Sequential, Agglomerative, Hierarchical, and Nested) statistical module and UPGMA (unweighted pair group method with arithmetic mean) clustering method.

\section{Sequence analyses and community structure}

The representative plasmids selected from each $16 \mathrm{~S}$ rRNA ARDRA analysis cluster were sequenced using Applied Biosystems ABI $3730 \times 1$ DNA analyser at SciGenom Labs Pvt. Ltd., Kochi, India. The sequences were screened for vector sequences using "VecScreen" (www.ncbi.nlm.nih. gov/VecScreen) and further edited and assembled using Gene Tool Lite1.0 (BioTools Incorporated). The sequence similarity search to database DNA sequences was performed in BLAST (www.ncbi.nlm.nih.gov/BLAST) [2]. The gene sequences were aligned using ClustalW, and the evolutionary history was inferred using the Maximum Likelihood method based on the Kimura 2-parameter model. The phylogeny was analysed in MEGA 6.06 software [101] with 1000 bootstrap. Though the clones were sequenced based on ARDRA clusters, the number of operational taxonomic units (OTUs) was assessed based on $97 \%$ sequence similarity criterion using Mothur v.1.12.3 [90]. The taxonomic composition of ZWE shrimp culture pond was visualized using Geneious R8 [47]. The gene sequences of bacterial and archaeal 16S rRNA in Geneious R8 were analysed using the RDP Classifier (Ribosomal Database Project Database) [111], and Krona visualization tool [73] represented a hierarchical graph showing the diversity and relative abundance. The taxonomic composition of $16 \mathrm{~S}$ rRNA genes was calculated using VITCOMIC (VIsualization tool for Taxonomic COmpositions of Mlcrobial Community) software [65]. The visualization tool plots a single figure from all sequences indicating the relative evolutionary distances. Each phylum name was designated with different font colour, and circles indicated similarity of sequence to the sequences in database $(80 \%, 85 \%, 90 \%, 95 \%$, and $100 \%$ BLAST similarity) and size of the dots indicated relative abundance.

For the analyses of ammonia oxidizers (functional genes for $A O A$ and $A O B$ and group specific 16SrRNA gene for 
anammox), clones $(\sim n=15)$ were randomly sequenced on Applied Biosystems ABI 3730 × 1DNA analyser at SciGenom Labs Pvt. Ltd., Kochi, India. The sequences obtained were vector screened using "VecScreen" tool (www.ncbi.nlm.nih. gov/VecScreen), further edited and assembled using Gene Tool Lite1.0 (BioToolsIncorporated). The sequence similarity search to database DNA sequences was performed in BLAST server (www.ncbi.nlm.nih.gov/BLAST) [2]. Phylogenetic analysis was carried out using ClustalW multiple alignments of gene sequences, and the Maximum Likelihood method phylogenetic tree (1000 bootstrap) was built in MEGA version 6.06 [99]. The genetic distance was calculated using Kimura 2-parameter model.

\section{Nucleotide sequence accession numbers}

The GenBank accession numbers of genes are bacterial 16S rRNA gene (JF428815-JF428837, JF428842-JF428862), archaeal 16S rRNA gene (JF428780 to JF428804), bacterial amoA gene (JF428805-JF428814, JX524531, and JX524532), archaeal amoA gene (JX524533-JX524543), and anammox bacteria-specific 16S rRNA gene (KC499605-KC499609, KC499611, and JX524516-JX524530).

\section{Results and discussion}

\subsection{Physicochemical properties of the study site}

The environmental parameters of the bioaugmented ZWE shrimp pond are summarized in Table 2. Among the two species of ammonia-nitrogen [85], unionized ammonia $\left(\mathrm{NH}_{3}-\mathrm{N}\right)$ is more toxic. The recommended safe and tolerable ammonia-N levels for post-larvae, nauplius, and adolescents of shrimps are $1.15 \mathrm{mg} \mathrm{L}^{-1}\left(0.10 \mathrm{mg} \mathrm{L}^{-1}\right.$ $\left.\mathrm{NH}_{3}-\mathrm{N}\right), 0.13 \mathrm{mg} \mathrm{L}^{-1}\left(0.01 \mathrm{mg} \mathrm{L}^{-1} \mathrm{NH}_{3}-\mathrm{N}\right)$, and $4.26 \mathrm{mg} \mathrm{L}^{-1}$ ammonia- $\mathrm{N}\left(0.08 \mathrm{mg} \mathrm{L}^{-1} \mathrm{NH}_{3}-\mathrm{N}\right)$, respectively $[13,14]$. If the ammonia conversion to nitrate is prevented, significant

Table 2 Physiochemical properties of bioaugmented zero-water exchange shrimp culture ponds $(n=5)$

\begin{tabular}{ll}
\hline Parameters & Values \\
\hline pH & $7.6 \pm 0.043$ \\
Salinity & $17 \mathrm{PSU}$ \\
Alkalinity & $65 \mathrm{mg} \mathrm{L}^{-1}$ \\
Total hardness & $3100 \mathrm{mg} \mathrm{CaCO}_{3} \mathrm{~L}^{-1}$ \\
Ammonia-N & $0.212 \pm 0.0706 \mathrm{mg} \mathrm{L}^{-1}$ \\
Nitrite-N & $0.0412 \pm 0.0014 \mathrm{mg} \mathrm{L}^{-1}$ \\
Nitrate-N & $0.00545 \pm 0.0008 \mathrm{mg} \mathrm{L}^{-1}$ \\
\hline
\end{tabular}

concentrations of nitrite are accumulated in the environment, and it may cause a decrease in the immunity, and increased susceptibility to infection [105]. A suggested safe level of $\mathrm{N}-\mathrm{NO}_{2}$ is $0.09 \mathrm{mg} \mathrm{L}^{-1}$ [21], and similarly, safe levels of nitrite- $\mathrm{N}\left(0.0412 \pm 0.0014 \mathrm{mg} \mathrm{L}^{-1}\right)$ were observed in the bioaugmented shrimp pond on the 85th day of culture. Prior to the harvest (85th day), when there were maximum nutrient and biomass load, an interesting observation was the low level of total ammonia-nitrogen (TAN). The low levels of TAN obtained in the present study comply with previous observations of low levels of TAN in bioaugmented ZWE shrimp culture pond throughout the culture period $[34,44]$. The low level of TAN was attained by the microbial degradative processes being carried out by the microbial community in the sediment of the ZWE pond. Therefore, bio-geochemically ammonia-oxidation gains a vital role in the ZWE system. In the ZWE system, microbial-mediated processes and players acquire more importance to maintain low levels of ammonia, and in this context, understanding microbial players in ammonia oxidation from the sediment will be helpful to highlight the role of microorganisms in bioaugmented ZWE shrimp culture ponds.

\section{Bacterial and archaeal 16S rRNA gene analysis of ZWE pond}

Metagenomic DNA of good yield and purity with a concentration of $35 \mu \mathrm{g} \mathrm{mL}^{-1}$ was obtained from the ZWE pond sediment sample (Fig. S1). The amplification of bacterial 16S rRNA (1500 base-pair (bp)) (Fig. S2a) and archaeal 16S rRNA (950 bp) genes (Fig. S2b) were successful. Similarly, the PCR analysis of functional genes of bacterial amoA gene (491 bp) (Fig. S3a), archaeal amoA (635 bp) (Fig. S3b), and planctomycetes group-specific 16S rRNA gene (478 bp) (Fig. S3c) was also successful, confirming the existence of all the three ammonia oxidizers in tropical shallow ZWE shrimp culture pond. The clone libraries of the 16S rRNA genes of bacterial and archaeal communities and ammonia oxidizers were successfully generated and similar approach of PCR and clone library analyses were carried out to study estuary [82], OMZ (oxygen minimum zone) of ocean [53,54], and varied environments.

The ARDRA of 128 bacterial (Fig. S4a, b) and 44 archaeal (Fig. S4c, d) positive clones showed diverse banding profiles, indicating the level of molecular heterogeneity among the bacterial and archaeal populations in the sediment. The banding patterns were analysed and grouped using NTSYSpc. Each group represents a specific banding pattern. Dendrogram of bacteria (Fig. S5) and archaea (Fig. S6) based on ARDRA profiling were generated. ARDRA of 128 bacterial clones resulted in a dendrogram 
consisting of 25 groups and few individual representative clones, from which 33 representative clones were selected and sequenced. Similarly, ARDRA of 44 archaeal clones resulted in 9 groups and individual representatives, from which 25 representative clones were selected for sequencing. The distance coefficient of the dendrogram of bacterial 16S rRNA gene clone library ranged from 0.87 to 1.00 , and the archaeal $16 \mathrm{~S}$ rRNA clone library ranged from 0.82 to 1.00. ARDRA profiling was used as a tool to analyse the genetic diversity of microbial communities from different environments $[64,78]$.

\section{Phylogenetic analysis of bacterial and archaeal 16S rRNA genes}

Based on a $3 \%$ cut-off, 33 bacterial clone sequences obtained from shrimp pond sediments were clustered into 29 OTUs (Fig.S7). Phylogenetic analysis (Fig. 1) of bacterial clones revealed Delta-Proteobacteria and Bacteroidetes as the most important bacterial communities in the bioaugmented ZWE shrimp pond. The clone sequences also showed similarity to the earlier reported uncultured Gamma-Proteobacteria [43], uncultured Nitrospira bacterium clone [1], uncultured Planctomycetales group, uncultured deep-sea bacterial clones, sulphate-reducing Olavius sp. [1, 49], uncultured Chloroflexi [103], Acidobacteria [1], Crocinitomix sp. [41], purple-sulphur bacteria (PBS)-Thiohalocapsa sp. [52, 74], Spirochaeta [35], Desulfuromonas, and Desulfucoccus. The bacterial communities in the bioaugmented ZWE shrimp pond showed similarity to mostly sulphur-oxidizing and reducing bacteria.

A total of 25 representative clones from the archaeal library clustered within 16 OTUs based on a 3\% cut-off (Fig.S7). Phylogenetic analysis (Fig. 2) of archaeal clones showed close affiliation to uncultured archaeal clones. To acquire an accurate description of phylogenetic relationships of ZWE shrimp pond sediment clones, we included representative sequences of both cultivated and uncultivated archaeal clones (showing maximum similarity) in the analysis. Based on their phylogenetic affiliation (Fig. 2), archaeal 16S rRNA gene sequences were seen distributed among Crenarchaeota and Thaumarchaeota. The isolated clones from ZWE pond showed similarity (>95\%) to sequences from habitats such as marine sediment $[25,38$, $61]$, mangrove and estuarine sediments [42, 94, 115], and thermal spring [113].

The Geneious R8 biodiversity map of the bacterial $16 \mathrm{~S}$ rRNA gene (Fig. 3) showed the presence of three proteobacterial classes and nine other major phyla. The bacterial communities in the ZWE pond were belonging to Proteobacteria, Bacteroidetes, Ignavibacteriae, Firmicutes, Gyanobacteria, Planctomycetes, Spirochaetes, Chloroflexi,
Hydrogenedentes, and Acidobacteria. The relative abundance of Proteobacteria accounts for $39 \%$, with a predominance of Delta-Proteobacteria (27\%), followed by Gamma-Proteobacteria (9\%) and Alpha-Proteobacteria (3\%). The Delta-Proteobacteria comprised the major representatives with 3\% Desulfuromonadaceae, 6\% Deferrisoma, 6\% Cystobacteraceae, 3\% Desulfobulbaceae, and $9 \%$ Desulfobacteraceae. The second relatively abundant Gamma-Proteobacteria represented 3\% Coxiellaceae, 3\% Chromatiaceae, and 3\% Ectothiorhodospiracaea. Rhodobacteraceae (3\%) was represented in the Alpha-Proteobacteria. Bacteroidetes (24\%) was another major representative followed by Proteobacteria, which showed the presence of Flavobacteria (9\% Cryomophaceae, and 6\% Flavobacteriaceae), Bacteroidia (6\% Prolixibacteraceae), and Cytophagia (3\% Flammeovirgaceae). Ignavibacteriaceae (12\%) was the third dominant group of bacteria in ZWE ponds. The remaining bacterial groups present in the bioaugmented ZWE pond were 3\% Thermoanaerobacterales and 3\% Clostridiales of Firmicutes, 3\% Gyanobacteria, 3\% Phycisphaeraceae of Planctomycetes, 3\% Spirochaetes, 3\% Dehalococcoidaceae of Chloroflexi, 3\% Candidatus Hydrogenedenes of Hydrogenedentes, and $3 \% \mathrm{Gp} 23$ genus of Acidobacteria Gp23. The VITCOMIC plot of the overall taxonomic composition of bacterial communities (Fig. 4) demonstrated the predominance of Proteobacteria and Bacteroidetes, with $\leq 5 \%$ relative abundance.

The presence of relevant microorganisms in the sediment metagenome signifies their contribution to the sulphur and nitrogen cycle in the ZWE shrimp pond. The presence of these microbial communities reflects the ecological functions that they could perform in the system. In the overall diversity of the sediment metagenome, the substantial fraction was comprised of DeltaProteobacteria. They are predominantly anaerobic genera containing sulphate and sulphur-reducing bacteria. The sequences affiliated to Desulfuromonas genera, Deferrisoma sp., Myxococcales, and Desulfobacterales order were detected. Genera Desulfuromonas (family Desulfuromonadaceae) are anaerobic bacterium, performing organic matter degradation and sulphur respiration [22, $23,76]$. Deferrisoma sp., a thermophilic, anaerobic, mixotrophic bacterium [75], could oxidize the electron donors completely into $\mathrm{CO}_{2}$ and $\mathrm{H}_{2} \mathrm{O}$ with elemental sulphur and iron (III) as electron acceptors [96]. Anaeromyxobacter sp., an anaerobic myxobacterium within the order Myxococcales, grows anaerobically with acetate oxidation and reduction of electron acceptors (oxygen, nitrate, nitrite, and fumarate). They are physiologically adapted to both oxic and anoxic conditions and found distributed throughout soil and sediment environments $[102,104]$. Sulphatereducing bacteria, Desulfobacterales, included among the Delta-Proteobacteria reduces sulphates to sulphides 
Fig. 1 Phylogenetic tree of bacterial $16 \mathrm{~S}$ rRNA genes from the sediment metagenome of bioaugmented zero-water exchange shrimp pond constructed using MEGA version 6.06 software with Maximum Likelihood method and Kimura 2-parameter model (1000 Bootstrap). Sequences of bacterial 16S rRNA gene obtained from the present study are represented using the symbol (घ) in the phylogenetic tree

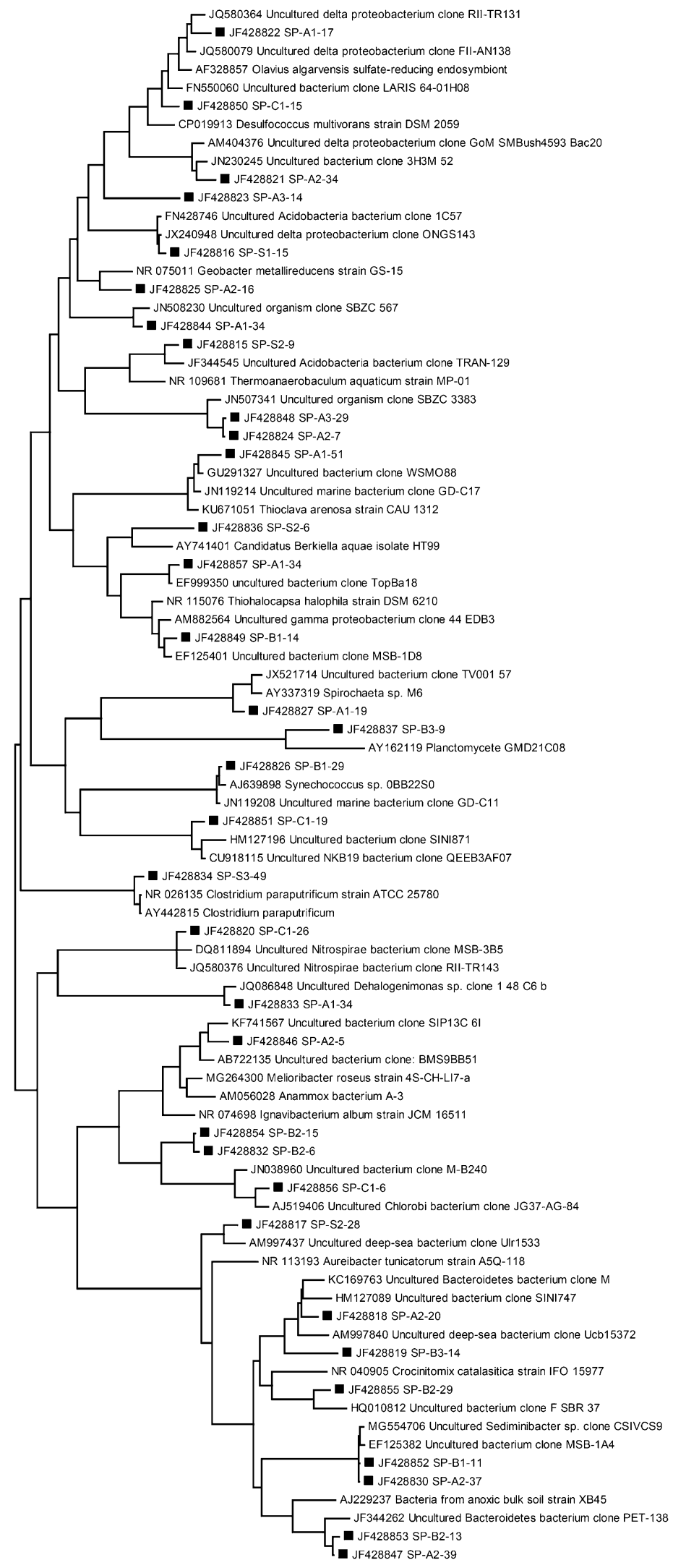

[JQ580364 Uncultured delta proteobacterium clone RII-TR131

L AF328857 Olavius ar GoM SMBush4593 Bac20

FN428746 Uncultured Acidobacteria bacterium clone 1 C57

X240948 Uncultured delta proteobacterium clone ONGS143

D JF 5280230

clone TRAN-129

m clone 44 EDB3

- JF428849 SP-B1-14

clone TV001 57

- JF428837 SP-B3-9

- JF428851 SP-C1-19

HM127196 Uncultured bacterium clone SINI87

JF428834 SP-S3-49

bacterium clone RII-TR143

JQ086848 Uncultured

KF741567 Uncultured bacterium clone SIP13C 6

F428832 SP-B2-6

JN038960 Uncultured bact

J 519406 Uncultured Chlorobi bacterium clone JG37-AG-84

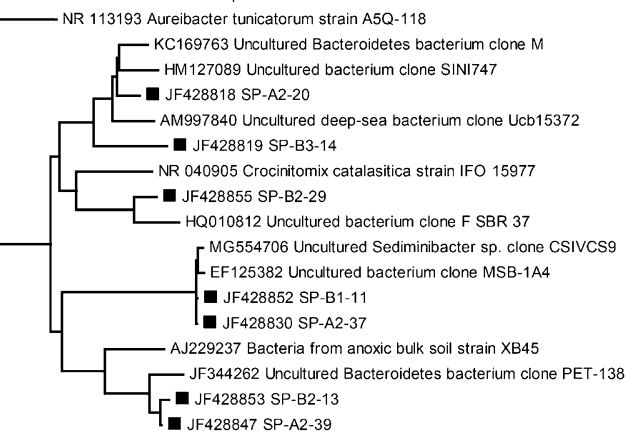


Fig. 2 Phylogenetic tree of archaeal 16S rRNA genes from the sediment metagenome of bioaugmented zero-water exchange shrimp pond was constructed using MEGA version 6.06 software with Maximum Likelihood method and Kimura 2-parameter model (1000 Bootstrap). Sequences of archaeal 16S rRNA gene obtained from the present study are represented using the symbol ( $\square$ ) in the phylogenetic tree

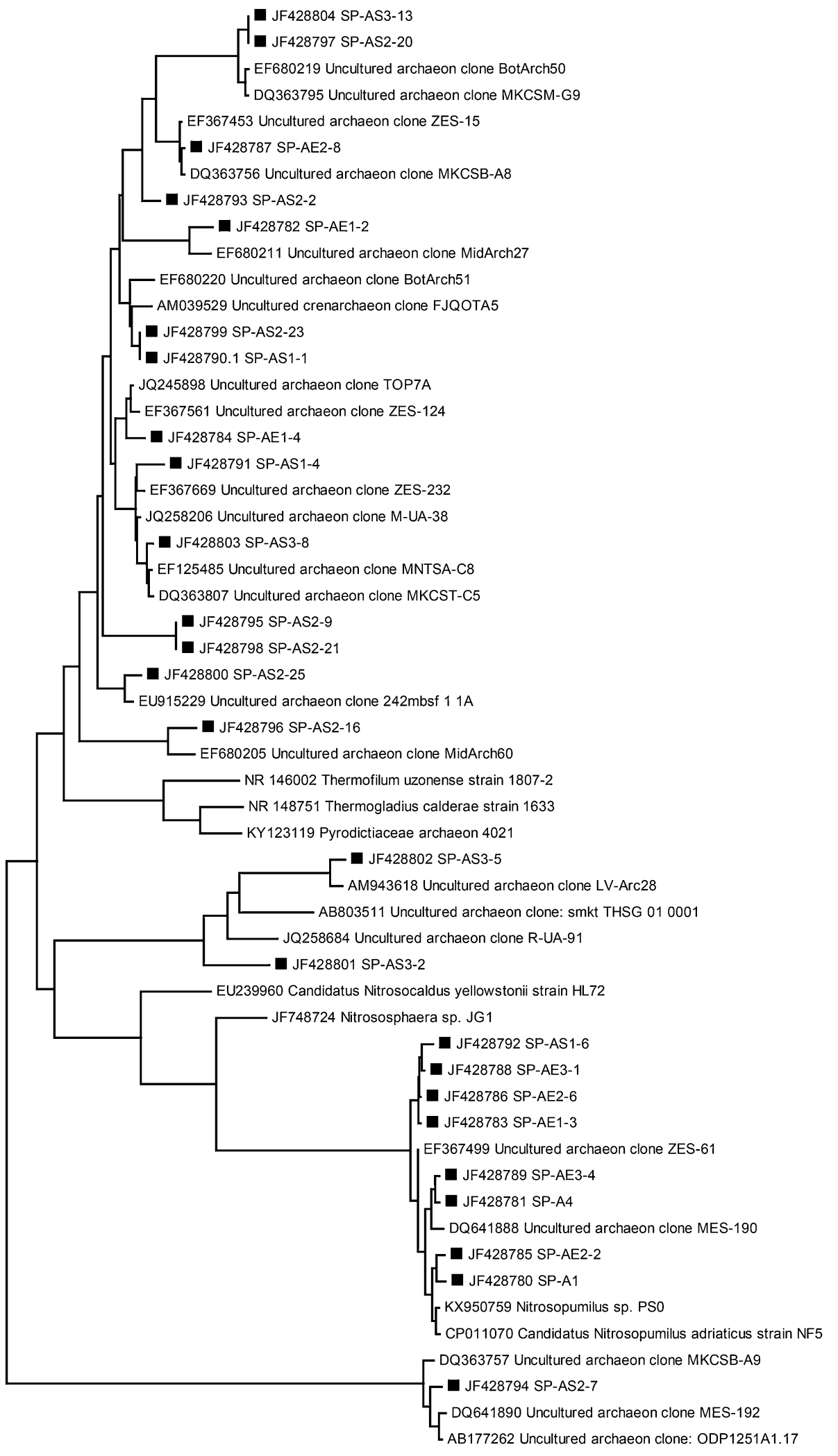




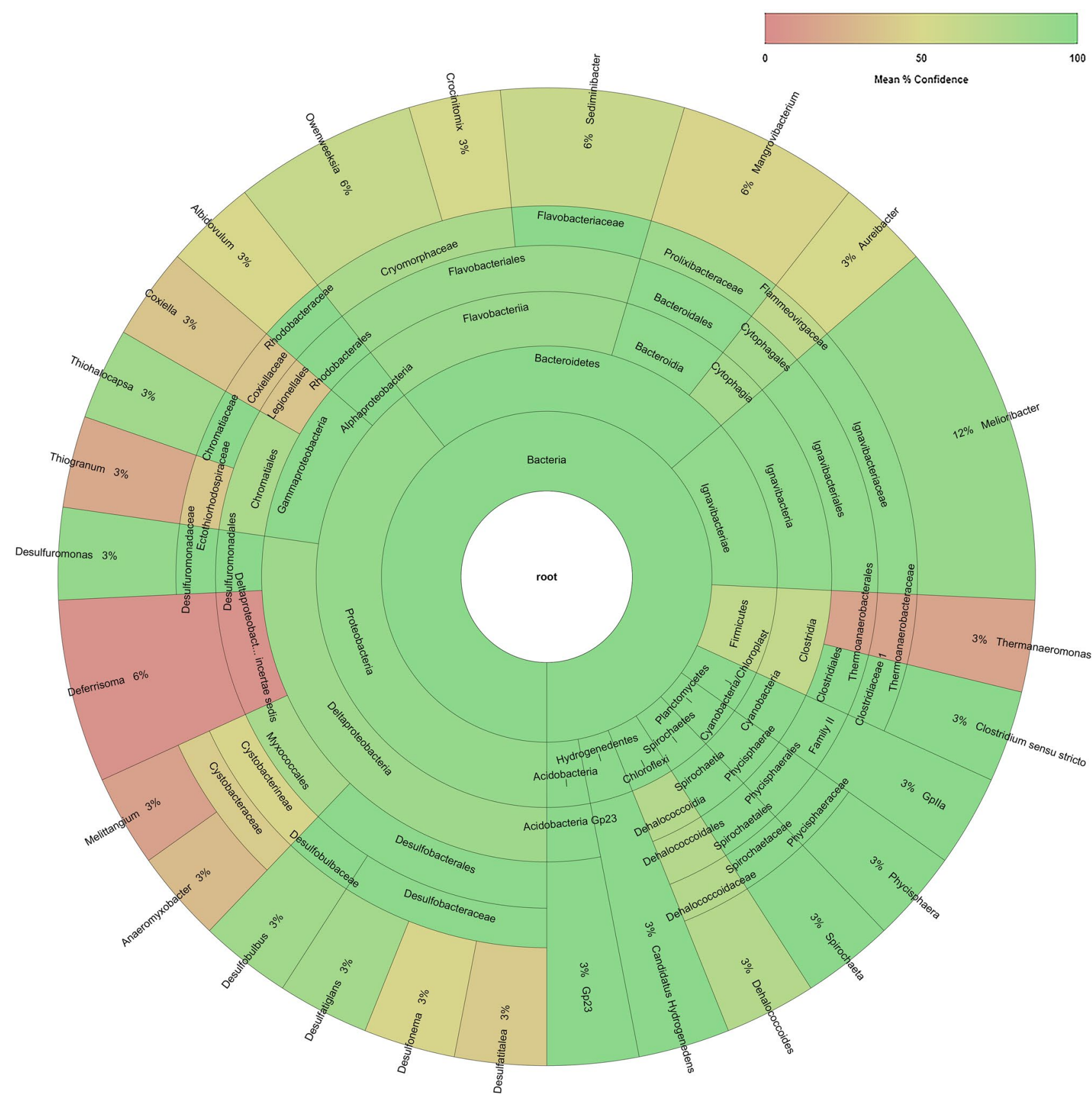

Fig. 3 Geneious map showing the distribution pattern of bacterial groups within the sediment metagenome of bioaugmented zero-water exchange shrimp pond

to obtain energy. Further, sequences associated with Thiohalocapsa sp. (family Chromatiaceae) and Thiogranum sp. (family Ectothiorhodospiraceae) of order Chromatiales belonging to Gamma-Proteobacteria were observed in the clone library analyses, denoting the prominent role of Gamma-Proteobacteria in sediments. The families of Chromatiaceae and Ectothiorhodospiraceae are found in marine ecosystems and consuming sulphide originating from active sulphate reduction as an electron donor [12]. Thiohalocapsa sp. is phototrophic, purple-sulphur bacteria (PSB) found in anoxic zones of a marine aquaculture pond sediment [52], and Thiogranum sp. of Ectothiorhodospiraceae are obligately chemolithoautotrophic, sulphur-oxidizing bacteria [67]. In addition, Rhodobacteraceae family of Alpha-Proteobacteria was observed in the clone library. This Rhodobacteraceae family comprises of 


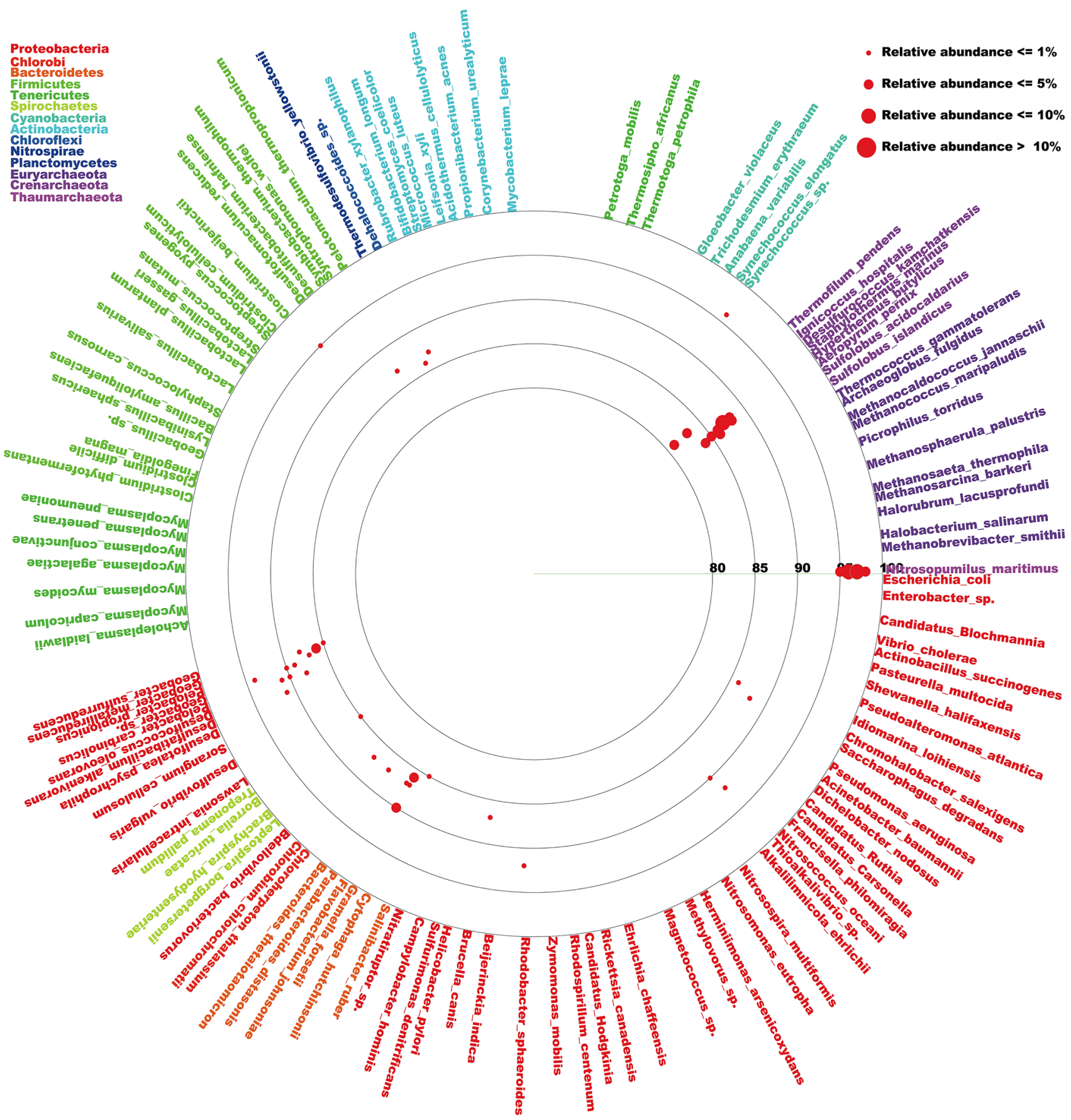

Fig. 4 VITCOMIC merged map results of bacterial and archaeal groups within the sediment metagenome of bioaugmented zero-water exchange shrimp pond

photoheterotrophs and chemoorganotrophs capable of nitrogen fixation and metabolize various sulphur-containing compounds [80].

The clone library also comprised sequences related to Bacteroidetes. Most of the sequences within Bacteroidetes were closely affiliated with Crymorphaceaea. Members of this group play a significant role in secondary production in aquatic ecosystems [9], playing a potential role in organic matter degradation [118]. The sequences related to Sediminibacter sp. of Flavobacteriaceae were detected. They are chemoheterotrophic bacterium [48], and some members of the Flavobacteria have potential to degrade complex carbon [18]. Few sequences were affiliated to Mangrovibacterium sp. (Prolixibacteraceae family), a nitrogen-fixing bacterium [37], and some sequences to a marine bacterium Aureibacter sp. (Flammeovirgaceae 
family) [116]. Sequences affiliated to Melioribacter sp. (class Ignavibacteria) were observed. Melioribacter sp. has glycoside hydrolases and transferases genes for polysaccharide degradation and synthesis, and they also possess genes encoding superoxide dismutase and catalase to detoxify the oxygen respiration by-products $[45,77]$. The sequence similarity to Firmicutes delineated the association with Thermanaeromonas sp. and Clostridium sensustricto. Thermanaeromonas $\mathrm{sp}$. are anaerobic, thermophilic bacteria, which use thiosulphate as an electron acceptor and can reduce nitrate and nitrite for growth $[46,66]$. Clostridium sensustricto, abundant Firmicutes in RAS (recirculating aquaculture systems), are reported to have the potential in removing the accumulated nitrate $[31,83]$. Very few sequences of Gplla genus belonging to Cyanobacteria family II [20] were also found. The 16S rRNA gene sequences associated with facultative anaerobe Phycisphaera sp. (third class of Planctomycetes) were present in the clone library; they perform nitrate-to-nitrite reduction under anaerobic conditions [27], also associated with fermentation at the sulphate-methane transition zone in marine sediments [33]. Species-specific sequence similarity to Spirochaeta genus was observed, which were ubiquitous inhabitants of many aquatic environments [74, 88], can colonize and form flocculent matter, and can metabolize carbohydrates [109]. Dehalococcoidaceae (Chloroflexi family) contains dehalogenation complex [122] and is significant indicator of the re-oxidation stage [56]. Acidobacteria Gp23 (Acidobacteria) are capable of nitrate and nitrite reduction. The presence of metabolically diverse bacterial groups in the sediment metagenome suggested their efficiency in cycling the carbon, nitrogen, and sulphur loads and thereby bringing out efficient bioremediation in the bioaugmented ZWE shrimp pond.

The Geneious R8 biodiversity map of archaeal 16S rRNA gene (Fig. 5) revealed the distribution patterns of archaea by demonstrating the presence of two major taxonomic classes, Thermoprotei of Phylum Crenarchaeota and Nitrosopumilales of phylum Thaumarchaeota. Thermoproteals, Desulfurococales, and Acidobales orders belonging to the Thermoprotei class (Phylum Crenarchaeota) were present. Phylogenetically, Thermoproteales included $44 \%$ Thermofilum genus, and Acidobales included $8 \%$ Caldisphaera genus. Desulfurococcales included $4 \%$ of Hyperthermus genus belonging to Caldisphaeraceae family and $12 \%$ of Stetteria genus belonging to Desulfurococcaceae family.

Phylum Crenarchaeota was found in the sediments of ZWE pond, with the archaebacterium Thermofilum, a genus of the thermophilic, anaerobic sulphur respiring Thermoproteales, relatively abundant in the archaeal clone library. The growth of these archaebacterium is dependent on peptides, sulphur, and $\mathrm{H}_{2} \mathrm{~S}$ [120]. Similarly, the genus
Caldisphaera (family Acidobales), a thermoacidophilic crenarchaeote, was present which was reported to grow anaerobically and heterotrophically and can be stimulated by the presence of sulphur [39]. Desulfurococcaceae are a family of anaerobic microorganisms belonging to the order Desulfurococcales. Stetteria is a genus (Desulfurococcaceae family), mixotrophic sulphur-dependent Crenarchaeotae, which need elemental sulphur as an external electron acceptor, and dependent on the presence of $\mathrm{H}_{2}$ for its growth. Hyperthermusbutylicus sp. is a hyper-thermophilic, sulphur-reducing archaebacterium [121]. The detection of these species in the archaeal clone library denoted the importance of archaea in sulphur cycling of the ZWE shrimp pond. Nitrosopumilus genus belonging to Thaumarchaeota accounted for $32 \%$, which are chemolithoautotrophic ammonia oxidizers. There are reports showing Nitrosopumilus sp. as the prominent AOA in the biofilter of shrimp RAS and aquaculture ponds [11,72]. The taxonomic composition of archaeal communities using VITCOMIC (Fig. 4) confirms that N. maritimus belonging to Thaumarchaeota was the most abundant archaeal group with a relative abundance $\leq 10 \%$, and similarity $>95 \%$. $N$. maritimus was reported as the major archaeal ammoniaoxidizer in marine sediment samples and zero-water exchange shrimp culture systems $[19,72]$.

Microorganisms are of great importance in pond ecosystem as it increases the self-purification capacity, in turn, improving the water quality and enhancing the growth and immunity of the cultured animals. Bacterial and archaeal clone library dictates the relative abundance of phyla related to sulphur geochemical cycling. Sulphur cycling is important in these ponds as un-ionized dissolved hydrogen sulphide is toxic, and sulphate reduction can account for over $50 \%$ of organic matter degradation [69]. The phyla Bacteroidetes was high in clones underscoring the enhanced capacity for organic matter degradation. Bacterial clone library also indicated the presence of a diverse bacterial group capable of nitrogen fixation, nitrate and nitrite reduction, and the archaeal clone library indicated the presence of ammonia oxidizers. Bioremediation of nitrogenous compounds is important as it removes the potentially toxic compounds ammonia and nitrite. Thus, the results of ARDRA and phylogenetic analysis (Mega 6.06, VITCOMIC, and Geneious map) depict the taxonomic composition of microbial community in the bioaugmentation ZWE shrimp pond sediment when there were the maximum biomass, inputs of feed, and metabolic wastes. 


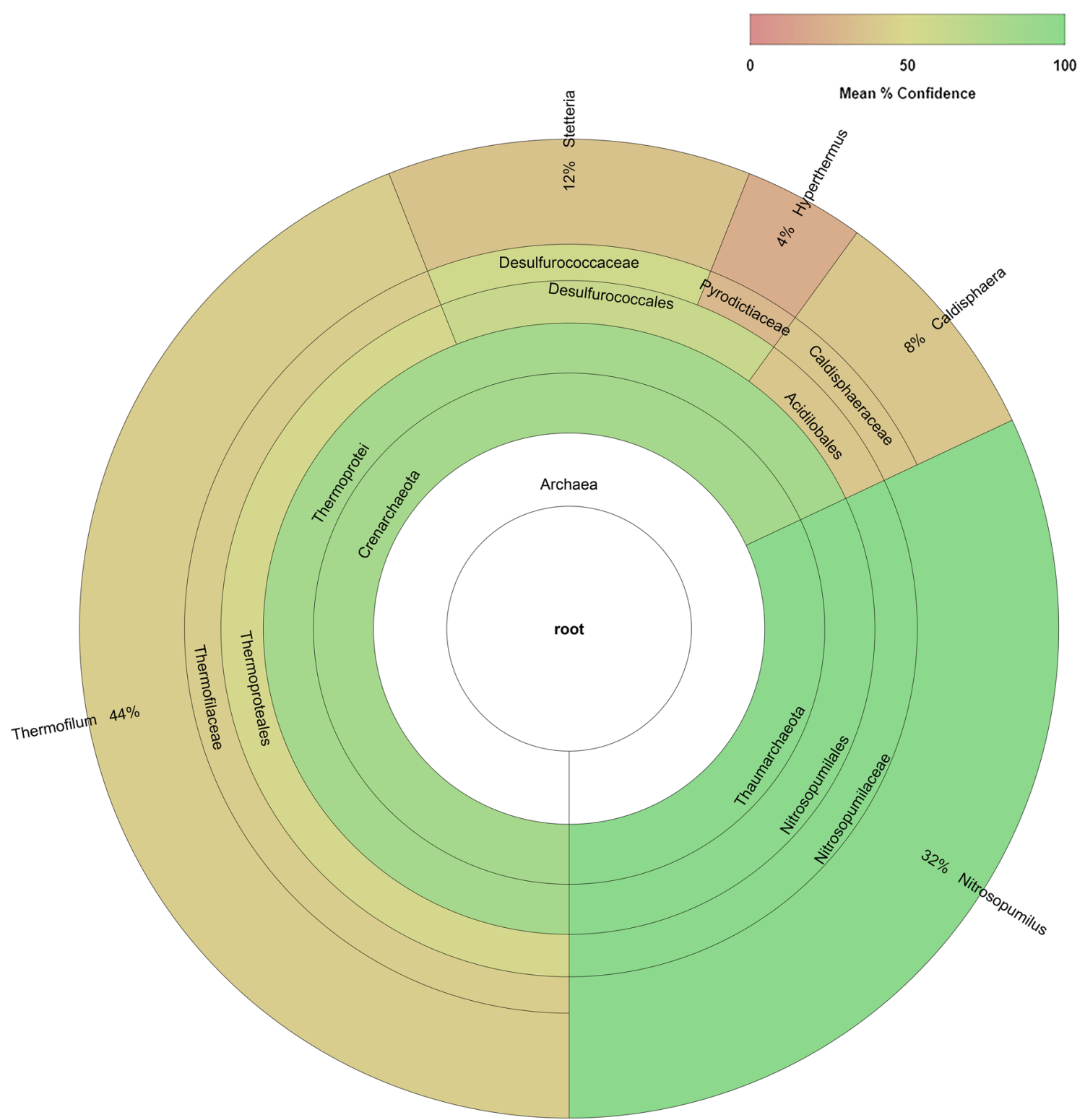

Fig. 5 Geneious map showing the distribution pattern of archaeal groups within the sediment metagenome of bioaugmented zero-water exchange shrimp pond

\section{Functional gene analyses of ammonia oxidizers in ZWE pond}

In this ZWE pond and earlier reports [34,44], the ammonia concentration was observed to be at a low level. Hence, the analysis of three major ammonia oxidizers ( $A O B$, $A O A$, and anammox) was conducted using bacterial- and archaeal-specific functional gene (amoA) and anammoxspecific 16S rRNA gene primer.

Nitrosomonas and Nitrosospira are the two major genera of $A O B$ [81]. Ammonia-rich ecosystems generally demonstrate the habitual predominance of Nitrosomonas sp. $[6,51]$. The bacterial amoA gene sequences showed $99 \%$ identity to uncultured AOB. Phylogenetic analysis (Fig. 6) showed similarity to the bacterial amoA gene of Nitrosomonas nitrosa [29]. Sequences also showed similarity to other uncultured bacterial amoA clones retrieved from bioreactors [28]. Based on the metagenomic sequence analysis, in the ZWE ponds, Nitrosomonas sp. represents the major AOB.

BLAST analyses of archaeal amoA gene sequences were similar to the ammonia monooxygenase gene of uncultured archaeon clone with an identity in the range of 96.7-99\%. The phylogenetic analyses (Fig. 7) of the archaeal amoA clones showed identity to amoA gene of uncultured crenarchaeote obtained from tropical 


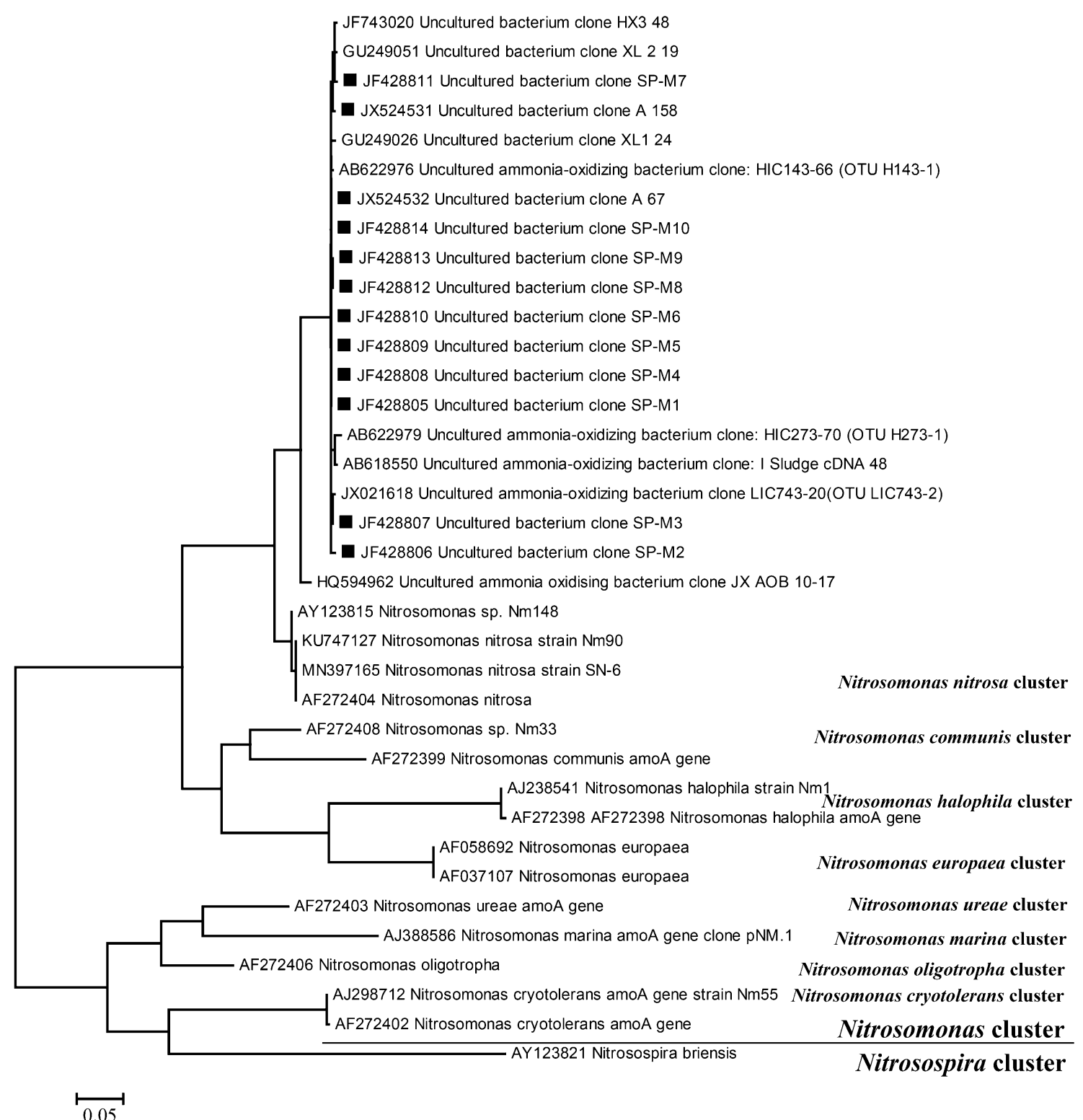

Fig. 6 Phylogenetic tree of uncultured $A O B$ clones obtained from the sediment metagenome of bioaugmented zero-water exchange shrimp pond constructed using MEGA version 6.06 software with Maximum Likelihood method and Kimura 2-parameter model

estuarine sediment [94], intertidal [7, 70], and mangrove [59] ecosystems. The archaeal amoA clones formed two distinct clusters, and the clone JX524541 was seen widely separated in the phylogenetic tree. Phylogenetic analyses with pure cultures excluding the uncultured environmental sequences showed $90 \%$ similarity with $99 \%$ coverage to Nitrosopumilus maritimus amoA gene of Thaumarchaeota phylum. These sequences were also similar to the Nitrosopumilus sequences retrieved from a biofilter of a shrimp RAS [11], except for clone JX524541. The clone JX524541 formed a distinct cluster that showed $81 \%$ similarity with
(1000 Bootstrap). Sequences of bacterial amoA obtained in the present study are represented using the symbol ( $\mathbf{\square})$ in the phylogenetic tree

99\% coverage to CandidatusNitrososphaera gargensis Ga9.2, belonging to phylum Thaumarchaeota of Nitrososphaera genus [97]. Based on the metagenomic sequence analysis, Nitrosopumilus sp. was the major AOA present in the ZWE ponds.

The Planctomycetae-specific 16S rRNA gene sequences were identical to uncultured Planctomycetes, Candidatus Kuenenia stuttgartiensis, and uncultured anammox bacteria, with a sequence similarity ranging from 98 to $99 \%$. Phylogenetic analysis (Fig. 8) showed similarity to the Candidatus Kuenenia from the sediments of mangrove, 


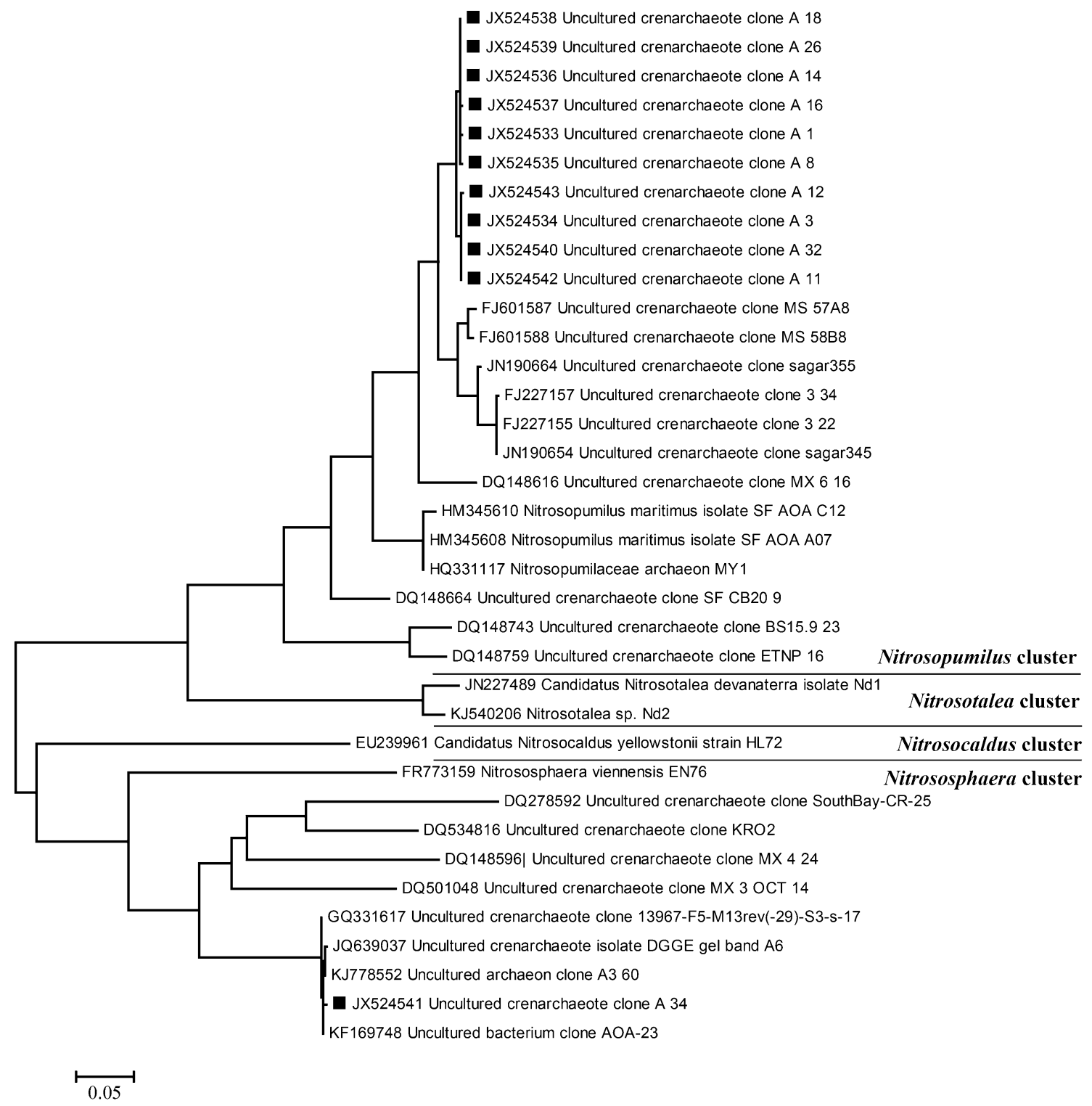

Fig. 7 Phylogenetic tree of uncultured AOA clones obtained from the sediment metagenome of bioaugmented zero-water exchange shrimp pond constructed using MEGA version 6.06 software with Maximum Likelihood method and Kimura 2-parameter model

estuary, and high-temperature reservoirs $[16,57,112]$. The presence of anammox in the pond bottom is very significant, as they play an active role in the conversion of ammonia to maintain it at low levels. There are reports on the survival of anammox in natural environments such as coastal, marine, natural freshwater wetland, aerated marine RAS, and anoxic zones of nitrifying biofilters [40, $92,100,106]$.

Nitrosomonas sp. (AOB), Nitrosopumilus sp. (AOA), and Candidatus Kuenenia (anammox) were predominant in the bioaugmented pond. All the three groups of ammonia oxidizers co-existed in the system, with
(1000 Bootstrap). Sequences of archaeal amoA obtained in the present study are represented using the symbol $(\square)$ in the phylogenetic tree

distinctly different mechanism of ammonia oxidation, substrate complementation, and metabolic interaction $[71,72]$. In oxic environments, ammonia is quickly oxidized by $A O B$ and $A O A$ [89]. Anammox bacteria have the ability to oxidize ammonia and reduce nitrite into $\mathrm{N}_{2}$ gas under anaerobic conditions, and their presence is widely seen in wastewater treatment plants, coastal marine sediments, estuaries, terrestrial habitats, oceanic and freshwater oxygen minimum zones $[17,54]$. The anaerobic ammonia-oxidation process by anammox is important to the aquaculture, as it removes both ammonia and nitrite, which is toxic to aquatic animals. 


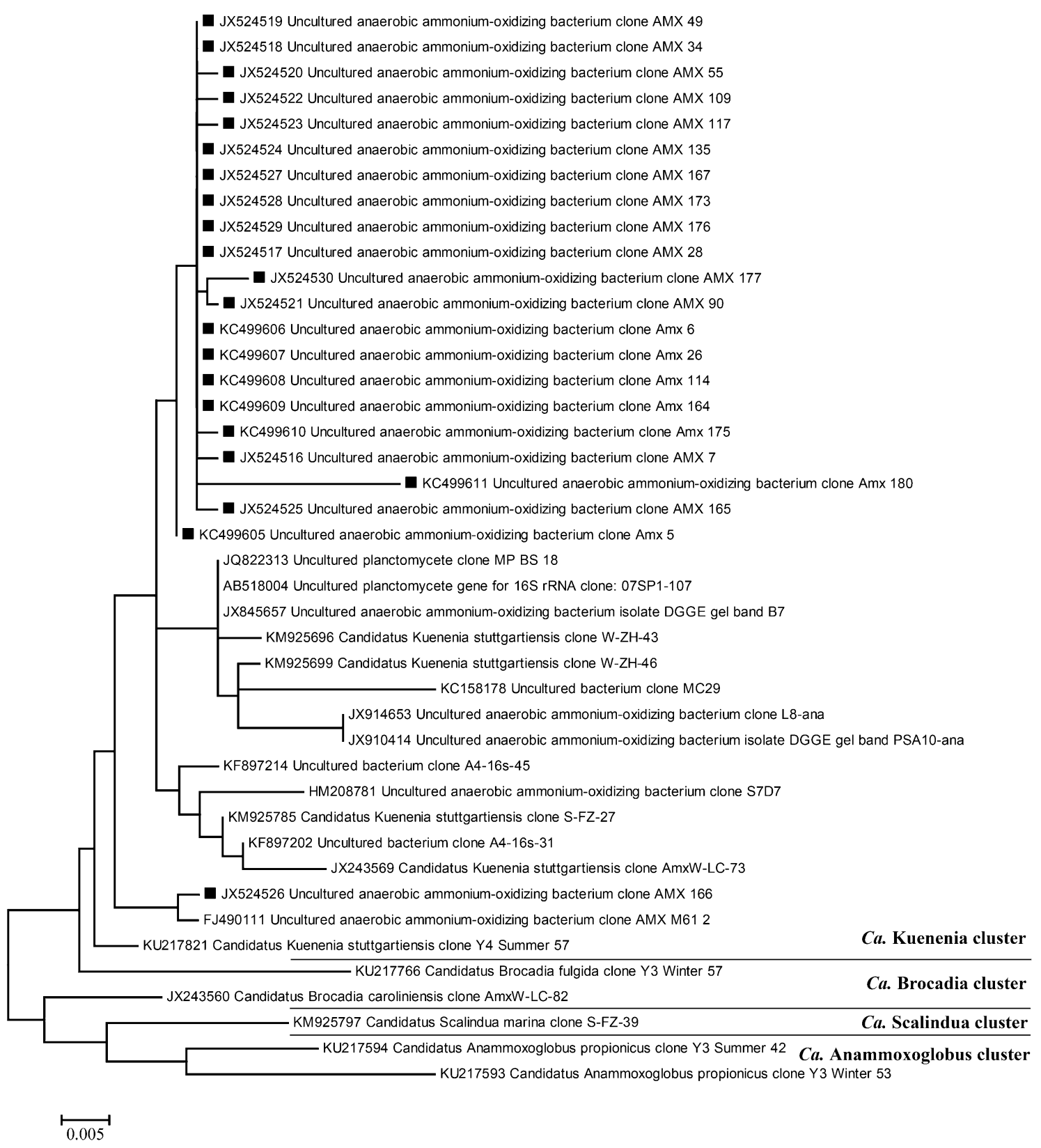

Fig. 8 Phylogenetic tree of uncultured anammox clones obtained from the sediment metagenome of bioaugmented zero-water exchange shrimp pond constructed using MEGA version 6.06 software with Maximum Likelihood method and Kimura 2-parameter

Usually, anammox bacteria are inhibited by the presence of oxygen, but can be detected in the aerated systems due to anoxic zones created by oxygen consumption and limited penetration of oxygen. The presence of $A O B$ and $A O A$ near anammox bacteria has a second great benefit model (1000 Bootstrap). Sequences of anammox 16S rRNA gene obtained in the present study are represented using the symbol ( $\square$ ) in the phylogenetic tree

since these organisms supply the nitrite by the oxidation of ammonia. Nitrite produced is required by anammox bacteria to oxidize ammonia [99]. The coexistence of $\mathrm{AOB}, \mathrm{AOA}$, and anammox would be ideal in aquaculture 
systems, to remove both ammonia and nitrite which are toxic to aquatic animals $[53,54,71,72]$.

\section{Conclusions}

Bacterial and archaeal communities involved in the sulphur, carbon, and nitrogen cycles were observed in ZWE shrimp culture pond sediment metagenome, which are critical in the maintenance of environmental quality and sustainability of the culture system. The phylogenetic analyses targeting ammonia oxidizers showed the presence of all the three communities $(A O B, A O A$, and anammox), indicating the key role of microbial communities in maintaining permissible or low levels of ammonia in the ZWE shrimp culture pond. The present study revealed the capability of the pond sediment to act as a bioreactor augmenting the removal of ammonia and nitrite from the culture systems, thus maintaining the optimal conditions required for aquaculture. The addition of the bioaugmentor, which is not a nitrifier, helped to degrade the organic matter and improve the environmental conditions to stimulate growth and activity of naturally occurring microbial communities. Altering the microbial ecology plays significant roles in nutrient cycling, thereby improving the survival and productivity of the cultured animals. Further knowledge on relevant microbial interactions and the overall ecology of these systems is essential for the successful management of the aquaculture systems.

Acknowledgements The authors acknowledge the Department of Science and Technology for the financial support to the present study under the Women Scientist Scheme (WOSA, F.No.41-568/2012 (SR) dated 18-07-2012). Ms. Geethu Chellappan and Ms. Aparajitha S. acknowledge the Department of Biotechnology for financial support under MTech. Marine Biotechnology programme.

\section{Compliance with ethical standards}

Conflict of interest The authors declare that they have no conflict of interest

Ethical approval This article does not contain any studies with human participants or animals performed by any of the authors.

Open Access This article is licensed under a Creative Commons Attribution 4.0 International License, which permits use, sharing, adaptation, distribution and reproduction in any medium or format, as long as you give appropriate credit to the original author(s) and the source, provide a link to the Creative Commons licence, and indicate if changes were made. The images or other third party material in this article are included in the article's Creative Commons licence, unless indicated otherwise in a credit line to the material. If material is not included in the article's Creative Commons licence and your intended use is not permitted by statutory regulation or exceeds the permitted use, you will need to obtain permission directly from the copyright holder. To view a copy of this licence, visit http://creativecommons .org/licenses/by/4.0/.

\section{References}

1. Acosta-González A, Rosselló-Móra R, Marqués S (2013) Characterization of the anaerobic microbial community in oil-polluted subtidal sediments: aromatic biodegradation potential after the prestige oil spill. Environ Microbiol 15:77-92. https://doi. org/10.1111/j.1462-2920.2012.02782.x

2. Altschul S (1997) Gapped BLAST and PSI-BLAST: a new generation of protein database search programs. Nucleic Acids Res 25:3389-3402. https://doi.org/10.1093/nar/25.17.3389

3. Amano T, Yoshinaga I, Okada K, Yamagishi T, Ueda S, Obuchi A, Sako Y, Suwa Y (2007) Detection of anammox activity and diversity of anammox bacteria-related 16S rRNA genes in coastal marine sediment in Japan. Microbes Environ 22:232242. https://doi.org/10.1264/jsme2.22.232

4. Amano T, Yoshinaga I, Yamagishi T, Thuoc CV, Thu PT, Ueda S, Kato K, Sako Y, Suwa Y (2011) Contribution of anammox bacteria to benthic nitrogen cycling in a mangrove forest and shrimp ponds, Haiphong. Vietnam Microbes Environ 26:1-6. https://doi.org/10.1264/jsme2.ME10150

5. APHA (2005) Standard methods for the examination of water and wastewater, 21 st edn. American Public Health Association, Washington D.C.

6. Ballinger SJ, Head IM, Curtis TP, Godley AR (1998) Molecular microbial ecology of nitrification in an activated sludge process treating refinery wastewater. Water Sci Technol 37:105108. https://doi.org/10.1016/S0273-1223(98)00091-2

7. Beman JM, Francis CA (2006) Diversity of ammonia-oxidizing archaea and bacteria in the sediments of a hypernutrified subtropical estuary: Bahía del Tóbari, Mexico. Appl Environ Microbiol 72:7767-7777. https://doi.org/10.1128/AEM.00946 $-06$

8. Bendschneider K, Robinson RJ (1952) A new spectrophotometric method for the determination of nitrite in sea water. J Mar Res 11:87-96

9. Bowman JP (2014) The Family Cryomorphaceae. In: Rosenberg E, DeLong EF, Lory S, Stackebrandt E, Thompson F (eds) The Prokaryotes. Springer, Berlin Heidelberg, Berlin, Heidelberg, pp 539-550. https://doi.org/10.1007/978-3-642-38954-2_135

10. Boyd CE (1985) Chemical budgets for channel catfish ponds. Trans Am Fish Soc 114:291-298. https://doi.org/10.1577/15488659(1985)114\%3c291:CBFCCP\%3e2.0.CO;2

11. Brown MN, Briones A, Diana J, Raskin L (2013) Ammonia-oxidizing archaea and nitrite-oxidizing nitrospiras in the biofilter of a shrimp recirculating aquaculture system. FEMS Microbiol Ecol 83:17-25. https://doi.org/10.1111/j.1574-6941.2012.01448.x

12. Caumette $P$ (1993) Ecology and physiology of phototrophic bacteria and sulfate-reducing bacteria in marine salterns. Experientia 49:473-481. https://doi.org/10.1007/BF01955148

13. Chen JC, Liu PC, Lei SC (1990) Toxicities of ammonia and nitrite to Penaeus monodon adolescents. Aquaculture 89:127-137. https://doi.org/10.1016/0044-8486(90)90305-7

14. Chin TS, Chen JC (1987) Acute toxicity of ammonia to larvae of the tiger prawn, Penaeus monodon. Aquaculture 66:247-253. https://doi.org/10.1016/0044-8486(87)90110-4

15. Crab R, Avnimelech Y, Defoirdt T, Bossier P, Verstraete W (2007) Nitrogen removal techniques in aquaculture for a sustainable production. Aquaculture 270:1-14. https://doi.org/10.1016/j. aquaculture.2007.05.006

16. Dale OR, Tobias CR, Song B (2009) Biogeographical distribution of diverse anaerobic ammonium oxidizing (anammox) bacteria 
in Cape Fear River Estuary. Environ Microbiol 11:1194-1207. https://doi.org/10.1111/j.1462-2920.2008.01850.x

17. Dalsgaard T, Thamdrup B, Canfield DE (2005) Anaerobic ammonium oxidation (anammox) in the marine environment. Res Microbiol 156:457-464. https://doi.org/10.1016/j.resmi c.2005.01.011

18. Darjany LE, Whitcraft CR, Dillon JG (2014) Lignocelluloseresponsive bacteria in a southern California salt marsh identified by stable isotope probing. Front Microbiol 5:263. https:// doi.org/10.3389/fmicb.2014.00263

19. Delong EF (1992) Archaea in coastal marine environments. Proc Natl Acad Sci USA 89:5685-5689. https://doi.org/10.1073/ pnas.89.12.5685

20. Erwin PM, Pita L, López-Legentil S, Turon X (2012) Stability of sponge-associated bacteria over large seasonal shifts in temperature and irradiance. Appl Environ Microbiol 78:7358-7368. https://doi.org/10.1128/AEM.02035-12

21. Ferreira NC, Bonetti C, Seiffert WQ (2011) Hydrological and water quality indices as management tools in marine shrimp culture. Aquaculture 318:425-433. https://doi.org/10.1016/j. aquaculture.2011.05.045

22. Finster K, Bak F, Pfennig N (1994) Desulfuromonasacetexigens sp. nov., a dissimilatory sulfur-reducing eubacterium from anoxic freshwater sediments. Arch Microbiol 161:328-332. https://doi.org/10.1007/BF00303588

23. Finster K, Coates JD, Liesack W, Pfennig N (1997) Desulfuromonasthiophila sp. nov., a new obligately sulfur-reducing bacterium from anoxic freshwater sediment. Int J Syst Bacteriol 47:754-758. https://doi.org/10.1099/00207713-47-3-754

24. Flegel TW (2009) Review of disease transmission risks from prawn products exported for human consumption. Aquaculture 290:179-189. https://doi.org/10.1016/j.aquacultur e.2009.02.036

25. Forschner SR, Sheffer R, Rowley DC, Smith DC (2009) Microbial diversity in cenozoic sediments recovered from the Lomonosov Ridge in the Central Arctic Basin. Environ Microbiol 11:630-639. https://doi.org/10.1111/j.1462-2920.2008.01834 .x

26. Francis CA, Roberts KJ, Beman JM, Santoro AE, Oakley BB (2005) Ubiquity and diversity of ammonia-oxidizing archaea in water columns and sediments of the ocean. Proc Natl Acad Sci USA 102:14683-14688. https://doi.org/10.1073/ pnas.0506625102

27. Fukunaga $Y$, Kurahashi $M$, Sakiyama $Y$, Ohuchi $M$, Yokota $A$, Harayama S (2009) Phycisphaeramikurensis gen. nov., sp. nov., isolated from a marine alga, and proposal of Phycisphaeraceae fam. nov., Phycisphaerales ord. nov. and Phycisphaerae classis nov. in the phylum Planctomycetes. J Gen Appl Microbiol 55:267-275. https://doi.org/10.2323/jgam.55.267

28. Fukushima T, Whang LM, Chiang TY, Lin YH, Chevalier LR, Chen MC, Wu YJ (2013) Nitrifying bacterial community structures and their nitrification performance under sufficient and limited inorganic carbon conditions. Appl Microbiol Biotechnol 97:6513-6523. https://doi.org/10.1007/s00253-012-4436-y

29. Fukushima T, Whang LM, Lee YC, Putri DW, Chen PC, Wu YJ (2014) Transcriptional responses of bacterial amoA gene to dimethyl sulfide inhibition in complex microbial communities. Bioresour Technol 165:137-144. https://doi.org/10.1016/j.biort ech.2014.03.003

30. Gray JP, Herwig RP (1996) Phylogenetic analysis of the bacterial communities in marine sediments. Appl Environ Microbiol 62:4049-4059 (PMID 8899989 PMCID PMC168226)

31. Gupta RS, Gao B (2009) Phylogenomic analyses of clostridia and identification of novel protein signatures that are specific to the genus Clostridium sensustricto (cluster I). Int J Syst Evol Microbiol 59:285-294. https://doi.org/10.1099/ijs.0.001792-0
32. Handelsman J, Rondon MR, Brady SF, Clardy J, Goodman RM (1998) Molecular biological access to the chemistry of unknown soil microbes: a new frontier for natural products. Chem Biol 5:R245-R249. https://doi.org/10.1016/S1074 $-5521(98) 90108-9$

33. Harrison BK, Zhang H, Berelson W, Orphan VJ (2009) Variations in archaeal and bacterial diversity associated with the sulfate-methane transition zone in continental margin sediments (Santa Barbara Basin, California). Appl Environ Microbiol 75:1487-1499. https://doi.org/10.1128/AEM.01812-08

34. Haseeb M (2012) Development of zero water exchange shrimp culture system integrated with bioremediation of detritus and ammonia-nitrogen. Cochin University of Science and Technology. http://dyuthi.cusat.ac.in/purl/3477

35. Headd B, Engel AS (2014) Biogeographic congruency among bacterial communities from terrestrial sulfidic springs. Front Microbiol 5:1-13. https://doi.org/10.3389/fmicb.2014.00473

36. Herbert RA (1999) Nitrogen cycling in coastal marine ecosystems. FEMS Microbiol Rev 23:563-590. https://doi. org/10.1111/j.1574-6976.1999.tb00414.x

37. Huang XF, Liu YJ, Dong JD, Qu LY, Zhang YY, Wang FZ, Tian XP, Zhang $S$ (2014) Mangrovibacteriumdiazotrophicum gen. nov., sp. nov., a nitrogen-fixing bacterium isolated from a mangrove sediment, and proposal of Prolixibacteraceae fam. nov. Int J Syst Evol Microbiol 64:875-881. https://doi.org/10.1099/ ijs.0.052779-0

38. Inagaki F, Nunoura T, Nakagawa S, Teske A, Lever M, Lauer A, Suzuki M, Takai K, Delwiche M, Colwell FS, Nealson KH, Horikoshi K, D'Hondt S, Jørgensen BB (2006) Biogeographical distribution and diversity of microbes in methane hydrate-bearing deep marine sediments on the Pacific Ocean Margin. Proc Natl Acad Sci USA 103:2815-2820. https://doi.org/10.1073/ pnas. 0511033103

39. Itoh T, Suzuki K, Sanchez PC, Nakase T (2003) Caldisphaeralagunensis gen. nov., sp. nov., a novel thermoacidophilic crenarchaeote isolated from a hot spring at Mt Maquiling. Philippines. Int J Syst Evol Microbiol 53:1149-1154. https://doi.org/10.1099/ ijs.0.02580-0

40. Jetten MSM, Niftrik LV, Strous M, Kartal B, Keltjens JT, Op den Camp HJM (2009) Biochemistry and molecular biology of anammox bacteria. Crit Rev Biochem Mol Biol 44:65-84. https ://doi.org/10.1080/10409230902722783

41. Ji Z, Chen Y (2010) Using sludge fermentation liquid to improve wastewater short-cut nitrification-denitrification and denitrifying phosphorus removal via nitrite. Environ Sci Technol 44:8957-8963. https://doi.org/10.1021/es102547n

42. Jiang L, Zheng $Y$, Chen J, Xiao X, Wang F (2011) Stratification of archaeal communities in shallow sediments of the Pearl River Estuary, Southern China. Antonie Van Leeuwenhoek 99:739751. https://doi.org/10.1007/s10482-011-9548-3

43. Jiang $L J$, Zheng YP, Peng XT, Zhou HY, Zhang CL, Xiao X, Wang FP (2009) Vertical distribution and diversity of sulfate-reducing prokaryotes in the Pearl River estuarine sediments, Southern China. FEMS Microbiol Ecol 70:249-262. https://doi.org/10.11 11/j.1574-6941.2009.00758.x

44. Joseph V, Haseeb M, Ranjit S, Anas A, Bright Singh IS (2014) Shrimp production under zero water exchange mode coupled with bioremediation and application of probiotics. J Fish Int 9:5-14. http://docsdrive.com/pdfs/medwelljournals/jfish /2014/5-14.pdf

45. Kadnikov VV, Mardanov AV, Podosokorskaya OA, Gavrilov SN, Kublanov IV, Beletsky AV, Bonch-Osmolovskaya EA, Ravin NV (2013) Genomic analysis of Melioribacter roseus, facultatively anaerobic organotrophic bacterium representing a novel deep lineage within Bacteriodetes/Chlorobigroup. PLoS ONE 8:e53047. https://doi.org/10.1371/journal.pone.0053047 
46. Kaksonen AH, Plumb JJ, Robertson WJ, Spring S, Schumann $P$, Franzmann PD, Puhakka JA (2006) Novel thermophilic sulfatereducing bacteria from a geothermally active underground mine in Japan. Appl Environ Microbiol 72:3759-3762. https:// doi.org/10.1128/AEM.72.5.3759-3762.2006

47. Kearse M, Moir R, Wilson A, Stones-Havas $S$, Cheung M, Sturrock S, Buxton S, Cooper A, Markowitz S, Duran C, Thierer T, Ashton B, Meintjes P, Drummond A (2012) Geneious Basic: An integrated and extendable desktop software platform for the organization and analysis of sequence data. Bioinformatics 28:1647-1649. https://doi.org/10.1093/bioinformatics/bts199

48. Khan ST, Nakagawa Y, Harayama S (2007) Sediminibacter furfurosus gen. nov., sp. nov. and Gilvibactersediminis gen. nov., novel members of the family Flavobacteriaceae. Int J Syst Evol Microbiol 57:265-269. https://doi.org/10.1099/ijs.0.64628-0

49. Kirk Harris J, Gregory Caporaso J, Walker JJ, Spear JR, Gold NJ, Robertson CE, Hugenholtz P, Goodrich J, McDonald D, Knights D, Marshall P, Tufo H, Knight R, Pace NR (2013) Phylogenetic stratigraphy in the Guerrero Negro hypersaline microbial mat. ISME J 7:50-60. https://doi.org/10.1038/ismej.2012.79

50. Krishnani KK (2010) Detection and diversity of nitrifying and denitrifying functional genes in coastal aquaculture. Aquaculture 302:57-70. https://doi.org/10.1016/j.aquacultur e.2010.01.024

51. Krishnani KK, Shekhar MS, Gopikrishna G, Gupta BP (2009) Molecular biological characterization and biostimulation of ammonia-oxidizing bacteria in brackish water aquaculture. J Environ Sci Health A 44:1598-1608. https://doi. org/10.1080/10934520903263637

52. Kumar AP, Srinivas TNR, Thiel V, Tank M, Sasikala C, Imhoff RCV, JF, (2009) Thiohalocapsa marina sp. nov., from an Indian marine aquaculture pond. Int J Syst Evol Microbiol 59:2333-2338. https ://doi.org/10.1099/ijs.0.003053-0

53. Lam P, Jensen MM, Lavik G, McGinnis DF, Müller B, Schubert CJ, Amann R, Thamdrup B, Kuypers MMM (2007) Linking crenarchaeal and bacterial nitrification to anammox in the Black Sea. Proc Natl Acad Sci USA 104:7104-7109. https://doi. org/10.1073/pnas.0611081104

54. Lam P, Lavik $G$, Jensen $M M$, van de Vossenberg J, Schmid M, Woebken D, Gutiérrez D, Amann R, Jetten MSM, Kuypers MMM (2009) Revising the nitrogen cycle in the Peruvian oxygen minimum zone. Proc Natl Acad Sci USA 106:4752-4757. https://doi. org/10.1073/pnas.0812444106

55. Lane DJ, Pace B, Olsen GJ, Stahl DA, Sogin ML, Pace NR (1985) Rapid determination of $16 \mathrm{~S}$ ribosomal RNA sequences for phylogenetic analyses. Proc Natl Acad Sci USA 82:6955-6959. https ://doi.org/10.1073/pnas.82.20.6955

56. Li B, Wu WM, Watson DB, Cardenas E, Chao Y, Phillips DH, Mehlhorn T, Lowe K, Kelly SD, Li P, Tao H, Tiedje JM, Criddle CS, Zhang T (2018) Bacterial community shift and coexisting/coexcluding patterns revealed by network analysis in a uranium-contaminated site after bioreduction followed by reoxidation. Appl Environ Microbiol 84:e02885-e2917. https://doi.org/10.1128/ AEM.02885-17

57. Li H, Chen S, Mu BZ, Gu JD (2010) Molecular detection of anaerobic ammonium-oxidizing (Anammox) bacteria in hightemperature petroleum reservoirs. Microb Ecol 60:771-783. https://doi.org/10.1007/s00248-010-9733-3

58. Li J, Nedwell DB, Beddow J, Dumbrell AJ, McKew BA, Thorpe EL, Whitby $C$ (2015) amoA gene abundances and nitrification potential rates suggest that benthic ammonia-oxidizing bacteria and not archaea dominate $\mathrm{N}$ cycling in the Colne Estuary, United Kingdom. Appl Environ Microbiol 81:159-165. https:// doi.org/10.1128/AEM.02654-1

59. Li M, Cao H, Hong Y, Gu JD (2011) Spatial distribution and abundances of ammonia-oxidizing archaea (AOA) and ammonia-oxidizing bacteria (AOB) in mangrove sediments. Appl Microbiol Biotechnol 89:1243-1254. https://doi. org/10.1007/s00253-010-2929-0

60. Li M, Gu JD (2016) The diversity and distribution of anammox bacteria in the marine aquaculture zones. Appl Microbiol Biotechnol 100:8943-8953. https://doi.org/10.1007/s0025 3-016-7690-6

61. Li Q, Wang F, Chen Z, Yin X, Xiao X (2012) Stratified active archaeal communities in the sediments of Jiulong River estuary. China Front Microbiol 3:311. https://doi.org/10.3389/fmicb .2012 .00311

62. Martínez Cruz P, Ibáñez AL, Monroy Hermosillo OA, Ramírez Saad HC (2012) Use of probiotics in aquaculture. ISRN Microbiol 2012:1-13. https://doi.org/10.5402/2012/916845

63. McCaig AE, Phillips CJ, Stephen JR, Kowalchuk GA, Martyn Harvey S, Herbert RA, Embley TM, Prosser JI (1999) Nitrogen cycling and community structure of proteobacterial $\beta$-Subgroup ammonia-oxidizing bacteria within polluted marine fish farm sediments. Appl Environ Microbiol 65:213-220. https://doi. org/10.1128/AEM.65.1.213-220.1999

64. Michaud L, Lo Giudice A, Troussellier M, Smedile F, Bruni V, Blancheton JP (2009) Phylogenetic characterization of the heterotrophic bacterial communities inhabiting a marine recirculating aquaculture system. J Appl Microbiol 107:1935-1946. https ://doi.org/10.1111/j.1365-2672.2009.04378.x

65. Mori H, Maruyama F, Kurokawa K (2010) VITCOMIC: visualization tool for taxonomic compositions of microbial communities based on 16S rRNA gene sequences. BMC Bioinformatics 11:332. https://doi.org/10.1186/1471-2105-11-332

66. Mori K (2002) Thermanaeromonastoyohensis gen. nov., sp. nov., a novel thermophilic anaerobe isolated from a subterranean vein in the Toyoha Mines. Int J Syst Evol Microbiol 52:16751680. https://doi.org/10.1099/ijs.0.02201-0

67. Mori K, Suzuki KI, Yamaguchi K, Urabe T, Hanada S (2015) Thiogranum longum gen. nov., sp. nov., an obligately chemolithoautotrophic, sulfur-oxidizing bacterium of the family Ectothiorhodospiraceae isolated from a deep-sea hydrothermal field, and an emended description of the genus Thiohalomonas. Int J Syst Evol Microbiol 65:235-241. https://doi. org/10.1099/ijs.0.070599-0

68. Moriarty DJW (1997) The role of microorganisms in aquaculture ponds. Aquaculture 151:333-349. https://doi.org/10.1016/ S0044-8486(96)01487-1

69. Muyzer G, Stams A (2008) The ecology and biotechnology of sulphate-reducing bacteria. Nat Rev Microbiol 6:441-454. https ://doi.org/10.1038/nrmicro1892

70. Nakaya A, Onodera Y, Nakagawa T, Satoh K, Takahashi R, Sasaki S, Tokuyama T (2009) Analysis of ammonia monooxygenase and archaeal $16 \mathrm{~S}$ rRNA gene fragments in nitrifying acid-sulfate soil microcosms. Microbes Environ 24:168-174. https://doi. org/10.1264/jsme2.ME09104

71. Nair RR, Boobal R, Vrinda S, Bright Singh IS, Valsamma J (2019) Ammonia-oxidizing bacterial and archaeal communities in tropical bioaugmented zero water exchange shrimp production systems. J Soils Sediments 19:2126-2142. https://doi. org/10.1007/s11368-018-2185-y

72. Nair RR, Rangaswamy B, Sarojini BSI, Joseph V (2020) Anaerobic ammonia-oxidizing bacteria in tropical bioaugmented zero water exchange aquaculture ponds. Environ Sci Pollut Res 27:10541-10552. https://doi.org/10.1007/s11356-020-07663-1

73. Ondov BD, Bergman NH, Phillippy AM (2011) Interactive metagenomic visualization in a Web browser. BMC Bioinform 12:385. https://doi.org/10.1186/1471-2105-12-385

74. Paissé S, Coulon F, Goñi-Urriza M, Peperzak L, McGenity TJ, Duran R (2008) Structure of bacterial communities along a hydrocarbon contamination gradient in a coastal sediment. 
FEMS Microbiol Ecol 66:295-305. https://doi.org/10.111 1/j.1574-6941.2008.00589.x

75. Pérez-Rodríguez I, Rawls M, Coykendall DK, Foustoukos DI (2016) Deferrisomapalaeochoriense sp. nov., a thermophilic, iron (III)-reducing bacterium from a shallow-water hydrothermal vent in the Mediterranean Sea. Int J Syst Evol Microbiol 66:830-836. https://doi.org/10.1099/ijsem.0.000798

76. Pfennig N, Biebl H (1976) Desulfuromonas acetoxidans gen. nov. and sp. nov., a new anaerobic, sulfur-reducing, acetateoxidizing bacterium. Arch Microbiol 110:3-12. https://doi. org/10.1007/BF00416962

77. Podosokorskaya OA, Kadnikov VV, Gavrilov SN, Mardanov AV, Merkel AY, Karnachuk OV, Ravin NV, Bonch-Osmolovskaya EA, Kublanov IV (2013) Characterization of Melioribacter roseus gen. nov., sp. nov., a novel facultatively anaerobic thermophilic cellulolytic bacterium from the class Ignavibacteria, and a proposal of a novel bacterial phylum Ignavibacteriae. Environ Microbiol 15:1759-1771. https://doi. org/10.1111/1462-2920.12067

78. Preena PG, Kumar VJR, Achuthan C, George R, Boobal R, Nair RR, Singh ISB (2018) Diversity of marine and brackish water nitriteoxidizing consortia developed for activating nitrifying bioreactors in aquaculture. Int J Environ Sci Technol 15:2399-2410. https://doi.org/10.1007/s13762-017-1580-z

79. Prosser Jl, Nicol GW (2008) Relative contributions of archaea and bacteria to aerobic ammonia oxidation in the environment. Environ Microbiol 10:2931-2941. https://doi.org/10.11 11/j.1462-2920.2008.01775.x

80. Pujalte MJ, Lucena T, Ruvira MA, Arahal DR, Macián MC (2014) The Family Rhodobacteraceae. In: Rosenberg E, DeLong EF, Lory S, Stackebrandt E, Thompson F (eds) The Prokaryotes. Springer, Berlin, Heidelberg, pp 439-512. https://doi. org/10.1007/978-3-642-30197-1_377

81. Purkhold U, Pommerening-Röser A, Juretschko S, Schmid MC, Koops HP, Wagner M (2000) Phylogeny of all recognized species of ammonia oxidizers based on comparative 16S rRNA and amoA sequence analysis: implications for molecular diversity surveys. Appl Environ Microbiol 66:5368-5382. https://doi. org/10.1128/AEM.66.12.5368-5382.2000.Updated

82. PuthiyaVeettil V, Abdulaziz A, Chekidhenkuzhiyil J, Ramkollath LK, Hamza FK, Kalam BK, Ravunnikutty MK, Nair S (2015) Bacterial domination over archaea in ammonia oxidation in a monsoon-driven tropical estuary. Microb Ecol 69:544-553. https://doi.org/10.1007/s00248-014-0519-x

83. Qiu T, Liu L, Gao M, Zhang L, Tursun H, Wang X (2016) Effects of solid-phase denitrification on the nitrate removal and bacterial community structure in recirculating aquaculture system. Biodegradation 27:165-178. https://doi.org/10.1007/s1053 2-016-9764-7

84. Riya G (2015) Bacillus cereus MCCB 101 as bioaugmentor for detritus degradation in a simulated zero water exchange shrimp grow out system. https://dyuthi.cusat.ac.in/xmlui/handl e/purl/5220

85. Romano N, Zeng C (2013) Toxic effects of ammonia, nitrite, and nitrate to decapod crustaceans: a review on factors influencing their toxicity, physiological consequences, and coping mechanisms. Rev Fish Sci 21:1-21. https://doi.org/10.1080/10641 262.2012.753404

86. Rotthauwe JH, Witzel KP, Liesack W (1997) The ammonia monooxygenase structural gene amoA as a functional marker: molecular fine-scale analysis of natural ammonia-oxidizing populations. Appl Environ Microbiol 63:4704-4712. https:// doi.org/10.1128/AEM.NA

87. Salencia HR, Mourino JLP, Ferreira GS, Arantes RF, Ubert M, Lapa KR, Seiffert WQ (2016) A bioaugmentation agent in super intensive marine shrimp farming system with zero water exchange.
J Aquac Res Dev 07:406. https://doi.org/10.4172/21559546.1000406

88. Santander-de Leon SMS, Reichardt W, Peralta-Milan S, San Diego-McGlone M, Nonato Nuñal S, Wei H, Yoshikawa T, Okunishi S, Maeda H (2016) Bacterial community composition of sediments from a milkfish Chanoschanos Forsskål farm. Aquac Res 47:2569-2581. https://doi.org/10.1111/are.12705

89. Santoro AE, Francis CA, de Sieyes NR, Boehm AB (2008) Shifts in the relative abundance of ammonia-oxidizing bacteria and archaea across physicochemical gradients in a subterranean estuary. Environ Microbiol 10:1068-1079. https://doi.org/10.1 111/j.1462-2920.2007.01547.x

90. Schloss PD, Westcott SL, Ryabin T, Hall JR, Hartmann M, Hollister EB, Lesniewski RA, Oakley BB, Parks DH, Robinson CJ, Sahl JW, Stres B, Thallinger GG, Van Horn DJ, Weber CF (2009) Introducing mothur: open-source, platform-independent, communitysupported software for describing and comparing microbial communities. Appl Environ Microbiol 75:7537-7541. https:// doi.org/10.1128/AEM.01541-09

91. Sesuk T, Powtongsook S, Nootong K (2009) Inorganic nitrogen control in a novel zero-water exchanged aquaculture system integrated with airlift-submerged fibrous nitrifying biofilters. Bioresour Technol 100:2088-2094. https://doi.org/10.1016/j. biortech.2008.10.027

92. Shen L, Wu H, Gao Z, Cheng H, Li J, Liu X, Ren Q (2016) Distribution and activity of anaerobic ammonium-oxidising bacteria in natural freshwater wetland soils. Appl Microbiol Biotechnol 100:3291-3300. https://doi.org/10.1007/s00253-015-7191-z

93. Sierra-Beltrán AP, Cortés-Altamirano R, Cortés-Lara MC (2005) Occurrences of Prorocentrum minimum (Pavillard) in México. Harmful Algae 4:507-517. https://doi.org/10.1016/j. hal.2004.08.018

94. Singh SK, Verma P, Ramaiah N, Chandrashekar A, Shouche YS (2010) Phylogenetic diversity of archaeal 16S rRNA and ammonia monooxygenase genes from tropical estuarine sediments on the central west coast of India. Res Microbiol 161:177-186. https://doi.org/10.1016/j.resmic.2010.01.008

95. Solorzano L (1969) Determination of ammonia in natural waters by the phenol hypochlorite method. Limnol Oceanogr 14:799-801. https://doi.org/10.4319/lo.1969.14.5.0799

96. Slobodkina GB, Reysenbach AL, Panteleeva AN, Kostrikina NA, I D Wagner D, Bonch-Osmolovskaya EA, Slobodkin AI, (2012) Deferrisomacamini gen. nov., sp. nov., a moderately thermophilic, dissimilatory iron (III)-reducing bacterium from a deepsea hydrothermal vent that forms a distinct phylogenetic branch in the Deltaproteobacteria. Int J Syst Evol Microbiol 62:2463-2468. https://doi.org/10.1099/ijs.0.038372-0

97. Spang A, Poehlein A, Offre P, Zumbrägel S, Haider S, Rychlik N, Nowka B, Schmeisser C, Lebedeva EV, Rattei T, Böhm C, Schmid M, Galushko A, Hatzenpichler R, Weinmaier T, Daniel R, Schleper C, Spieck E, Streit W, Wagner M (2012) The genome of the ammonia-oxidizing Candidatus Nitrososphaera gargensis: insights into metabolic versatility and environmental adaptations. Environ Microbiol 14:3122-3145. https://doi.org/10.111 1/j.1462-2920.2012.02893.x

98. Strickland JDH, Parsons TR (1972) A practical handbook of sea water analysis. In: Fisheries Research Board of Canada, 2nd Edn. Bulletin of Fisheries Research Board of Canada, Canada.

99. Strous M, Pelletier E, Mangenot S, Rattei T, Lehner A, Taylor MW, Horn M, Daims H, Bartol-Mavel D, Wincker P, Barbe V, Fonknechten $N$, Vallenet $D$, Segurens $B$, Schenowitz-Truong $C$, Médigue C, Collingro A, Snel B, Dutilh BE, Op den Camp HJ, van der Drift C, Cirpus I, van de Pas-Schoonen KT, Harhangi HR, van Niftrik L, Schmid M, Keltjens J, van de Vossenberg J, Kartal B, Meier $H$, Frishman D, Huynen MA, Mewes HW, Weissenbach J, Jetten MS, Wagner M, Le Paslier D (2006) Deciphering the evolution 
and metabolism of an anammox bacterium from a community genome. Nature 440:790-794. https://doi.org/10.1038/natur e04647

100. Tal Y, Watts JEM, Schreier SB, Sowers KR, Schreier HJ (2003) Characterization of the microbial community and nitrogen transformation processes associated with moving bed bioreactors in a closed recirculated mariculture system. Aquaculture 215:187-202. https://doi.org/10.1016/S0044-8486(02)00372-1

101. Tamura K, Stecher G, Peterson D, Filipski A, Kumar S (2013) MEGA6: Molecular evolutionary genetics analysis version 6.0. Mol Biol Evol 30:2725-2729. https://doi.org/10.1093/molbev/ mst197

102. Thomas SH, Wagner RD, Arakaki AK, Skolnick J, Kirby JR, Shimkets LJ, Sanford RA, Löffler FE (2008) The mosaic genome of Anaeromyxobacter dehalogenans strain $2 \mathrm{CP}-\mathrm{C}$ suggests an aerobic common ancestor to the delta-proteobacteria. PLoS ONE 3:e2103. https://doi.org/10.1371/journal.pone.0002103

103. Tischer K, Kleinsteuber S, Schleinitz KM, Fetzer I, Spott O, StangeF LU, Franz J, Neumann F, Gerling S, Schmidt C, Hasselwander $\mathrm{E}$, Harms $\mathrm{H}$, Wendeberg A (2013) Microbial communities along biogeochemical gradients in a hydrocarboncontaminated aquifer. Environ Microbiol 15:2603-2615. https ://doi.org/10.1111/1462-2920.12168

104. Treude N, Rosencrantz D, Liesack W, Schnell S (2003) Strain FAc12, a dissimilatory iron-reducing member of the Anaeromyxobacter subgroup of Myxococcales. FEMS Microbiol Ecol 44:261-269. https://doi.org/10.1016/S0168-6496(03)00048-5

105. Tseng I (2004) The immune response of white shrimp Litopenaeus vannamei and its susceptibility to Vibrio alginolyticus under nitrite stress. Fish Shellfish Immunol 17:325-333. https ://doi.org/10.1016/j.fsi.2004.04.010

106. van Kessel MAHJ, Harhangi HR, Flik G, Jetten MSM, Klaren PHM, Op den Camp HJM (2011) Anammox bacteria in different compartments of recirculating aquaculture systems. Biochem Soc Trans 39:1817-1821. https://doi.org/10.1042/BST20110743

107. van Kessel MAHJ, Harhangi $H R$, van de Pas-Schoonen $K$, van de Vossenberg J, Flik G, Jetten MSM, Klaren PHM, Op den Camp HJM (2010) Biodiversity of $\mathrm{N}$-cycle bacteria in nitrogen removing moving bed biofilters for freshwater recirculating aquaculture systems. Aquaculture 306:177-184. https://doi. org/10.1016/j.aquaculture.2010.05.019

108. Venter JC (2004) Environmental genome shotgun sequencing of the Sargasso Sea. Science 304:66-74. https://doi. org/10.1126/science.1093857

109. Verhoeven J, Salvo F, Hamoutene D, Dufour S (2016) Bacterial community composition of flocculent matter under a salmonid aquaculture site in Newfoundland, Canada. Aquac Environ Interact 8:637-646. https://doi.org/10.3354/aei00204

110. Wang JK (1990) Managing shrimp pond water to reduce discharge problems. Aquac Eng 9:61-73. https://doi. org/10.1016/0144-8609(90)90011-N

111. Wang Q, Garrity GM, Tiedje JM, Cole JR (2007) Naive Bayesian classifier for rapid assignment of rRNA sequences into the new bacterial taxonomy. Appl Environ Microbiol 73:5261-5267. https://doi.org/10.1128/AEM.00062-07
112. Wang S, Hong Y, Wu J, Xu XR, Bin L, Pan Y, Guan F, Wen J (2015) Comparative analysis of two $16 \mathrm{~S}$ rRNA gene-based PCR primer sets provides insight into the diversity distribution patterns of anammox bacteria in different environments. Appl Microbiol Biotechnol 99:8163-8176. https://doi.org/10.1007/s0025 3-015-6814-8

113. Weidler GW, Dornmayr-Pfaffenhuemer M, Gerbl FW, Heinen W, Stan-Lotter H (2007) Communities of archaea and bacteria in a subsurface radioactive thermal spring in the Austrian Central Alps, and evidence of ammonia-oxidizing Crenarchaeota. Appl Environ Microbiol 73:259-270. https://doi.org/10.1128/ AEM.01570-06

114. Weisburg WG, Barns SM, Pelletier DA, Lane DJ (1991) 16S ribosomal DNA amplification for phylogenetic study. J Bacteriol 173:697-703. https://doi.org/10.1128/jb.173.2.697-703.1991

115. Yan B, Hong K, Yu ZN (2006) Archaeal communities in mangrove soil characterized by $16 \mathrm{~S}$ rRNA gene clones. J Microbiol 44:566-571 (PMID: 17082752)

116. Yoon J, Adachi K, Park S, Kasai H, Yokota A (2011) Aureibactertunicatorum gen. nov., sp. nov., a marine bacterium isolated from a coral reef sea squirt, and description of Flammeovirgaceae fam. nov. Int J Syst Evol Microbiol 61:2342-2347. https://doi. org/10.1099/ijs.0.027573-0

117. Yuvaraj D, Karthik R (2015) Efficacy of Probiotics on Litopenaeus vannamei culture through zero water exchange system. J Fish Aquat Sci 10:445-463. https://doi.org/10.3923/ jfas.2015.445.463

118. Zeng Y, Zou Y, Chen B, Grebmeier JM, Li H, Yu Y, Zheng T (2011) Phylogenetic diversity of sediment bacteria in the Northern Bering Sea. Polar Biol 34:907-919. https://doi.org/10.1007/ s00300-010-0947-0

119. Zhou Z, Li H, Song C, Cao X, Zhou Y (2017) Prevalence of ammonia-oxidizing bacteria over ammonia-oxidizing archaea in sediments as related to nutrient loading in Chinese aquaculture ponds. J Soils Sediments 17:1928-1938. https://doi. org/10.1007/s11368-017-1651-2

120. Zillig W, Gierl A, Schreiber G, Wunderl S, Janekovic D, Stetter KO, Klenk HP (1983) The archaebacterium thermofilum pendens represents, a novel genus of the thermophilic, anaerobic sulfur respiring thermoproteales. Syst Appl Microbiol 4:79-87. https ://doi.org/10.1016/S0723-2020(83)80035-6

121. Zillig W, Holz I, Wunderl S (1991) Hyperthermusbutylicus gen. nov., sp. nov., a hyperthermophilic, anaerobic, peptidefermenting, facultatively $\mathrm{H} 2 \mathrm{~S}$-generating archaebacterium. Int J Syst Bacteriol 41:169-170. https://doi.org/10.1099/00207 713-41-1-169

122. Zinder SH (2016) Dehalococcoides has a dehalogenation complex. Environ Microbiol 18:2773-2775. https://doi. org/10.1111/1462-2920.13204

Publisher's Note Springer Nature remains neutral with regard to jurisdictional claims in published maps and institutional affiliations. 